\title{
An accurate evaluation of water availability in sub-arid Mediterranean watersheds through SWAT: Cega-Eresma-Adaja
}

David Rivas-Tabares(1), Ana M. Tarquis (1,2), Bárbara Willaarts(3), Ángel De Miguel (4)

(1) Universidad Politécnica de Madrid (UPM), CEIGRAM. Madrid, Spain,

(2)Grupo de Sistemas Complejos, Universidad Politécnica de Madrid (UPM), Madrid, Spain

(3) International Institute for Applied System Analysis (IIASA), Vienna, Austria,

(4) Wageningen Environmental Research (WENR), Wageningen, The Netherlands. 


\section{Abstract}

Simulation of flow processes in hyper-regulated Mediterranean watersheds is critical when examining general water demand and established ecological flows of River Basin Management Plans. Weather dynamics in the Mediterranean zone in recent decades have been characterised by a natural variation of drought cycles. In addition, exacerbated climate change proves that water fluxes must be estimated with more exhaustive models. The aim of this study is to assess the water balance of the CegaEresma-Adaja (CEA) watershed, including a detailed assessment of land uses and management practices to quantify agricultural water demand for the time period 2004-2014. We used the Soil and Water Assessment Tool (SWAT), given that it is a widespread tool that involves complex processes of the water cycle on a basin scale, providing information on water dynamics related to land use as a fundamental characteristic for water balance calculation. The Nash-Sutcliffe coefficient efficiency value, the main index of calibration and validation performance, was 0.86 for the Eresma-Adaja River and 0.67 for the Cega River. This presents a good result considering the large-scale watershed studied. Analysing dry hydrological years, we found that the estimation of ecological flows for sub-arid zones needs to consider the shallow aquifer-river relationship. During spring-summer periods, with very low flow, monitoring the shallow aquifer levels ensures a good ecological status. The study reveals that aspects such as crop rotation, soil management and their associated measures in Mediterranean basins are key factors for water resource management during drought periods. These results are expected to serve stakeholders and river basin authorities in conducting better-integrated water management practices in the watershed. 


\section{Introduction}

Water availability in the Mediterranean zone has been a subject of research in recent decades, and its assessment on a basin scale is a priority to secure water availability for different users, including fresh water, industry, agriculture and hydropower in southern Europe (Calbó, 2010; Giorgi and Lionello, 2008; Rafael et al., 2010). Agriculture is the major water user in Europe, accounting on average for $32 \%$ of total freshwater abstractions (EUROSTAT, 2017). In southern Europe, agricultural abstractions are greater, accounting for an average of $52 \%$ of total freshwater abstractions (EUROSTAT, 2017). In sub-arid climates, agricultural water extractions can reach $80 \%$, and often become a source of disputes amount water users (European Comission, 2012). The usual implementation of flow regulation strategies in these areas to meet increasing water demands, through reservoirs and artificial recharge of aquifers, captures the majority of the surface flow of rivers and results in a low flow system affecting riverine ecosystems and water availability (Tharme, 2003).

In Mediterranean watersheds of southern Europe, irrigated agriculture is a common strategy to ensure crop production and is considered a key driver in water scarcity (Psomas et al., 2016). Because of this, agricultural water demand must be reformulated, based on an integrated land use management approach, considering both irrigated and rainfed crops. Specific mitigation and adaptation measures for water resources management are needed to reconcile water demands from multiple users, as outlined in the River Basin Management Plans (RBMPs) (European Comission, 2012; European Environment Agency, 2015). The EU 2020 strategy and the Water Framework Directive (WFD) have been promoting several policies for water savings and its protection. Additionally, the Programme of Measures (PoMs) aims to achieve a satisfactory status for surface and groundwater bodies. Several tools, such as remote sensing, are used to identify land uses and the application of hydrological models to quantify real and potential water demand for agriculture.

Consequently, a sustainable management vision of water resources at watershed scale requires the inclusion of some measures at plot scale. Hence, through modelling, the 
cumulative effect of detailed land operations could be assessed for the watershed water fluxes. Hydrology models that include water fluxes related to land use can help decision makers formulate strategies in the water-energy-land-food nexus (Dodds and Bartram, 2016; Hoff et al., 2012). Furthermore, the water balance model alone is not enough; the environmental situation, the inclusion of hydrological dynamics in changing environments (Wang et al., 2016), climate change (Narsimlu et al., 2013), land use (Zhao et al., 2016), crop practices (Ullrich and Volk, 2009) and reservoir operation schedules (Kalogeropoulos et al., 2011) are also required to achieve an integrated water management scheme.

River basin authorities (RBA) use water management models as a tool to assess and guarantee water demands. Those models serve to manage water fluxes based on predefined and estimated water demands (e.g. water supply, irrigation and industry) and the associated regulatory infrastructure. Nevertheless, water balance is dynamic in time and space. Hence, to improve water management, more variables must be included to achieve a more accurate water balance. The water balance must include land use dynamics and cropland practices. The sensitivity of water availability in the catchment could be modified due to land use change for future water demands. This is why detailed hydrological models can be very useful tools for planning purposes.

As in any modelling exercise, hydrological models assume simplifications of a realbasin system and some degree of uncertainty is thus unavoidable. Therefore, the assumed simplifications should be considered cautiously, as they could affect the results. For example, if water demand by land use is expected, as a result, simplifications of this subject must be fully described by the model.

The SWAT is a spatially, semi-distributed and physically-based eco-hydrological model, developed by the USDA Agricultural Research Service. The application of SWAT, unlike other hydrological water management models, includes the viability of agricultural water demand in space and time. The model is largely used to evaluate the impact on land management over extended periods of time (Arnold et al., 1998). The use of SWAT as a tool to assess daily stream flows helps improve the general 
water balance, providing a new modelling trend for RBMPs. This water balance is influenced by crop rotations and farm practices, obtaining a better quantification and understanding of land management decisions in the watershed hydrology (Seeboonruang, 2012). At the same time, governments make an effort collecting accurate data from remote sensing and surveys. These have recently been used for the SWAT model setup (Ashraf Vaghefi et al., 2015; Guzinski et al., 2014; Laurent and Ruelland, 2011).

The aim of this study is to assess the water balance of the Cega-Eresma-Adaja (CEA), a Mediterranean watershed currently facing serious water stress, mainly as a result of a growing water demand for irrigation, compounded by increasing urbanisation. During the period from 2010-2016, the CEA was considered one of the most profitable areas for farming in Spain due to the expansion in horticultural production (Antequera et al., 2014). However, the growing demand for water is rapidly deteriorating the status of existing water bodies and threatening the sustainability of the basin and its economic activities. The situation may be worsening, as the RBMP (2015-2021) forecasts an increase of $18 \%$ (equivalent to 7,000 ha) in the current irrigated area by 2027, despite the existing water gap. The purpose of this research is also to establish a comparison between RBA estimates for agricultural water demand, and model results will be provided to study the sustainability of the irrigated area expansion in the catchment.

\section{Materials and Methods}

\subsection{Study area}

The CEA is located in the central north of the Iberian Peninsula, and consists of two adjacent sub-basins that are jointly defined as a hydrological management system by the Douro River Basin Authority (DRBA) (Figure 1). The stream network defined by the Eresma and Adaja sub-basins represents 67\% of the total CEA area, while the watershed defined by the Cega comprises 33\%. The former are regulated at the upper river network, while Cega is not yet regulated. 
The Eresma and Adaja sub-basin, with a total discharge of $407 \mathrm{hm}^{3} \mathrm{yr}^{-1}$, equivalent to $63 \%$ of the total discharge capacity of the CEA and the Cega sub-basin, provides the remaining $37 \%$ of CEA discharge $\left(238 \mathrm{hm}^{3} \mathrm{yr}^{-1}\right)$. Most of the rivers in the CEA system are directly connected to the aquifers (IGME, 2008). The frequent descent of the water table level, due to overexploitation, is causing a disconnection between the riverbed and the aquifer. This situation is exacerbated in dry periods, where most of the rivers have very low flows (CHD, 2015).

Nine major soil groups could be found in the area: Cambisols (34\%), Luvisol (26\%), Arenosols (19\%), Leptosol (11.5\%), Fluvisols (4\%), Regosol (3\%), Solonetz (1\%), Solonchak (1\%) and Gleysol (0.5\%). The soil genesis is typically developed from moorland limestone in the northeast, Mesozoic carbonates in the headwater area and is detritic in the basin landfill (IGME, 2009). Sandy soils are the representative

textures in more than $54 \%$ of the area, causing medium-high infiltration rates to subsurface flow to streams and recharge of groundwater bodies.

Agriculture is the main land use, accounting for $54.1 \%$ of the total area (Figure 2), followed by forestry $(27 \%)$, urban (12\%), shrubland and pastures $(6.7 \%)$, and water bodies $(0.1 \%)$. Rainfed crops represent $63 \%$ of total agricultural land, whereas fallow land accounts for $31 \%$, irrigated annual crops for $5 \%$, and permanent crops represent $1 \%$.

\subsection{SWAT model}

SWAT operates on a daily time step and this allows the assessment of hydrological parameters that are related to certain management practices. Thus, priority areas for improvement of soil and water management could be identified (Kaur et al., 2004)(Tripathi et al., 2003). The model presents a GIS-based environment (ArcSWAT) that is useful in defining watershed boundaries and their sub-basins. These sub-basins are subsequently divided into Hydrologic Response Units (HRUs), which are unique combinations of homogeneous land use types, soil characteristics, management practices and slopes (Gassman et al., 2007), and at the scale at which SWAT simulates the water balance. The representation of the catchment by HRUs is a simplification 
able to reproduce very detailed biophysical processes. These processes are associated with water dynamics, nutrient cycling, crop growth, agricultural management, sedimentation patterns and the implications of regulation infrastructure (Mauro et al., 2005). SWAT provides a distributed description of hydrological processes from HRU to sub-basin level.

Water balance can be defined in the watershed and at any stream point defined by the user (Neitsch et al., 2005). SWAT solves the water dynamics between infiltration/runoff ratio (SCS curve number method), evapotranspiration (land cover, vegetation stage and management dependency), percolation (including soil properties), lateral flow (topographic dependency), channel routing (main and tributary) and aquifer recharge relations (Moriasi et al., 2012). Complementary information on management operations is needed to depict global land management and its influence on watershed hydric behaviour (Neitsch et al., 2002).

\subsection{Model baseline setup}

The present study uses the SWAT2012_rev664 version with ArcSWAT 2012.10.19. Simulation is performed based on a daily time step (2004-2014). Model setup is summarised in Figure 3. In addition to the standard setup process, this work introduces some improvements in the setup related to input data to reduce model uncertainty.

Detailed descriptions and sources of the data used to set up the SWAT baseline model are provided in Table 1. The complete data for model setup were based on (i) measured data (e.g. soil samples), (ii) literature values from published studies, reports and official documentation of RBMPs, (iii) assumptions reported in the literature (e.g. soil parameters based on pedotransfer functions PTF) and (iv) SWAT predefined databases (e.g. crop parameters). As the scale of the CEA is wide, detailed management schedules associated with land uses have been included to elucidate their impact on the global water balance. (See Table A in supplementary material for more detailed information). 
CEA boundaries and sub-basins were defined using a 25-m DEM (Digital Elevation Map). An internal sub-basin division was also performed based on interest evaluation points: flow gauge locations, reservoir discharges and predefined sub-basins of DRBA. In total, 121 were defined for the CEA system, including 79 for the EA and 42 for the Cega catchment, each comprising different HRUs.

The CEA system, with ten reservoirs, is considered a hyper-regulated system, with all the reservoirs located in the headwaters of the Eresma-Adaja watershed (capacity of $81.24 \mathrm{hm}^{3}$ ). Discharge data on three reservoirs representing $86.8 \%$ of the total capacity are available and therefore considered for the simulations: Las Cogotas (56.8 $\mathrm{hm}^{3}$ ), Serones $\left(6.3 \mathrm{hm}^{3}\right)$ and Pontón Alto $\left(7.4 \mathrm{hm}^{3}\right)$. The discharges from reservoirs were included in the model, following the operation rules and their volume capacity. The input required was estimated and fitted by analysing the global behaviour of gauging discharge series during the simulation period.

From the 20 gauging stations located in the CEA system, only two provided daily stream flow data for the selected period (2004-2014): Valdestillas (VFG) monitored a northerly outlet covering $98.6 \%$ of the Eresma-Adaja watershed; and Lastras de Cuellar (LCFG), located in the middle of the Cega watershed, covered just $25 \%$ of the total area.

Weather data assignation is a key step in the development of a SWAT model, as any error introduced with the water input would propagate in the whole model. SWAT usually assigns the data of the nearest weather station to the sub-basin centroid, providing a constant value to the whole sub-basin. This could introduce a remarkable model input uncertainty, especially in large sub-basins where weather could be spatially heterogeneous in very steep reliefs. But as (Wagner et al., 2012) remarks, the definition of a composite climatic value by different weights using diverse interpolation methods significantly improves weather input for the model. This is why the weather data assignation was improved, including a spatial-based representativeness of data for each sub-basin. To do so, an implementation of the Thiessen Polygon Method (TPM) (Thiessen, 1911) was carried out. This method 
allows the assignment of values by weighted portion of the climate variable to the overlapping polygon area of each sub-basin (Figure 4). Thus, 121 artificial weather stations were created assigning weighted climate values to the centroid for each subbasin using the TPM method.

Definition of soil properties is also a key input for SWAT. A soil taxonomic unit map is currently available in the area with a scale of 1:400,000 (Figure 5). However, this map does not include soil properties. A common practice is to use pedotranfer functions to assign the soil properties required to the taxonomic units, affecting the uncertainty of the model (Seeger, 2007). To reduce it, a soil map was created using data from a soil sample database with 11 soil properties (clay percentage, sand percentage, silt percentage, moist soil albedo, available water content, wilting point, field capacity, saturated hydraulic capacity, bulk density, organic carbon content and organic content percentage) and the Kohonen in R tool (Wehrens and Buydens, 2007). Soil units in SWAT are directly related with the total number of HRUs. This tool reduces the number of soil units without losing spatial information. The Kohonen tool is based on the self-organising maps (SOMs) approach to delimit soil clusters. Each cluster defines a soil unit with a low variability of physical properties. Spatial variation of each soil parameter is complex in each unit, and different soil map scale analysis is required (Lin et al., 2005). The resulting clusters do not directly correspond to the taxonomic units, although they are interlinked. A close relationship does not apply in this context. (Figure 5). On the one hand, SOM represents clustering of soil properties and on the other, the taxonomy unit represents soil pedogenesis. However, spatial variability of soils properties is more complex.

To evaluate the SOM process, two performance metrics were implemented: the mean distance (deviation) from the cluster centroid (Grieco et al., 2017) and the DeviesBoulding (DB) index (Davies and Bouldin, 1979). Deviation metrics define the algorithm that minimises an error function computed on the sum of squared distances for each data point in each cluster. Low DB values represent low intra- and high intercluster variability, indicating a more satisfactory mathematical cluster result. The 
similar spatial distribution of clusters and taxonomic units is suitable. Therefore, this comparison serves to validate the SOM soils map.

In a traditional crop rotation setup, once the HRUs are defined, each HRU is assumed to have a homogeneous land use type, and therefore it rotates entirely. However, reality does not follow HRU boundaries for crop rotation. HRUs need to be fragmented (HRU_FR) and crop rotation results in a mosaic of crops representing the crop plots year by year. The land use model setup for crop rotations was improved with respect to traditional rotations by activating the land use change (LUC) module. Specific management operations and scheduling for the HRU_FR (e.g. irrigation, fertilisation, etc.) were considering by adding lines in the crop database with new codes for land uses with different operations. This was in the case of the same crops but with different crop management (e.g. rainfed winter wheat "WWHT", irrigated winter wheat "WWHI", etc.). The HRU_FR considers the different land operations as an independent calculation. At the end, the HRU water balance values are the results of this land use dynamic.

Data for crop updates were extracted from remote sensing processed images (ITACyl, 2015). The SWAT2009 LUU tool (Pai and Saraswat, 2011) was implemented to assign land cover from the satellite images (2004-2014) to the corresponding spatial HRU (see Table B, in supplementary material for more detailed information). This geospatial tool provides the required files to update the HRUs with the corresponding percentage (HRU_FR) of LUU (Land Use Update) on specific dates defined by the user. The surface flow configuration during rainfall events is related to surface roughness and slope. Consequently, crop rotation is essential for the runoff process. Curve number $(\mathrm{CN})$ is an important parameter for predicting direct runoff and infiltration process.

\subsection{Calibration and validation}

During the modelling run process, a warm-up period must be selected in order to ensure the establishment of basic flow conditions for the simulations. Following Kim et al., 2018, taking into account that sandy soils are predominant in the area, a one- 
year period (year 2003) was selected to warm up the model. The hydrologic processes need to reach an equilibrium condition for better results during calibration and validation.

Calibration is a procedure to reduce model output uncertainty by adjusting model parameters to obtain a model representation that satisfies pre-agreed criteria. In this research, calibration is performed by comparing the daily streamflow output for the period (2005-2009) with the corresponding measured values. Validation is the process in which the adjusted parameters were assessed in an additional period of time (2010-2014) to corroborate the accuracy of the adjustment, assessing model output uncertainty.

Hydrological models have some parameters that cannot be measured directly (Spaaks and Bouten, 2013). The main measured parameter of water flow in the watersheds is the streamflow, which serves as reference to determine other water flows indirectly (Morán-Tejeda et al., 2010). In hydrology modelling, streamflow is one of the measures used for calibration and validation (Benedini and Tsakiris, 2013). Other measures such as surface runoff, ground water recharge and evapotranspiration, among others, are hard to measure and the data available are limited to specific points in time and space.

Model calibration, validation and sensitivity analysis were performed using the algorithm for Sequential Uncertainty Fitting (SUFI-2). This is included in the SWATCUP package (Abbaspour, 2011). This process was settled for each of the two subbasins of the CEA at a daily time step. SUFI-2 is an algorithm that tries to capture most of the measured data within the $95 \%$ prediction uncertainty (95PPU) of the model using the selected parameter ranges during an iteration process consisting of 3001000 simulations (Abbaspour et al., 2015).

Automatic calibration processes were conducted with a previous parameter analysis through trial runs (10-100 simulations). During this trial, the final selected parameters for calibration and validation were identified by the sensitivity analysis of variables related with stream flow. Homogeneous flow time series lengths for both 
processes were selected to provide consistent statistical samples and to assess the more recent available data. Nevertheless, a good correlation during validation could be an erratic result due to cumulative model input uncertainties.

\subsection{Model performance evaluation}

The model's performance was assessed through statistical indices of the SUFI2 algorithm, a Bayesian framework to reduce the uncertainty during the sequential and fitting process of some objective function. Suitable ranges for Nash-Sutcliffe efficiency coefficient (NSE) (Nash and Sutcliffe, 1970), coefficient of determination $\left(\mathrm{R}^{2}\right)$, and percentage bias (PBIAS) were selected to measure the global matching and relative peak matching of simulated flow with SWAT (Gassman et al., 2007).

The NSE was selected as the objective function for evaluating simulation performance. $\mathrm{R}^{2}$ and PBIAS are complementary statistical criteria for efficiency statistics. The NSE is valid for ranges between $-\infty$ to 1 , where values between 0.0 and 1.0 represent acceptable levels of model performance. However, while values up to 0.5 show a satisfactory rating, even values up to 0.65 are usually considered good results and values between $(0.75-1.0)$ are considered very good performance (Moriasi et al., 2007). As statistical criterion of performance, the Kling-Gupta Efficiency (KGE) was selected. Similar to NSE, KGE represents the correlation, bias and relative variability between observed and simulated values. KGE values range from $-\infty$ to 1 , and the optimal value is 1 .

Model uncertainty was also evaluated, including R-factor (thickness of the 95PPU envelop) and P-factor (as the percentage of observed data enveloped by the modelling results) criteria, to constrain valid parameter ranges for CEA system modelling. Both judge the strength of the calibration and validation processes. Desirable ranges for the P-factor $(>0.7)$ and R-factor $(<1.5)$ were targeted to capture most of the matching observed flow into the 95PPU band of the model during an iterative process of a defined group of simulations (Abbaspour et al., 2004). 


\section{Results and Discussion}

\subsection{SWAT model setup improvements}

In the case of the weather data assignment, a water input difference of around $+14 \%$ $(59 \mathrm{~mm} / \mathrm{yr})$ was found between the method of weather direct assignation by centroid and the proposed TPM methodology (Figure 4). This is a considerable volume difference compared to the mean stream flow of the CEA system (EA with $57 \mathrm{~mm} / \mathrm{yr}$ and Cega River with $83 \mathrm{~mm} / \mathrm{yr}$ ) and to mean rainfall in CEA (427mm/yr). Other authors also found differences between both methods. For example, Pande et al., (1978) reported a water input difference of $+13 \%$ from the arithmetic mean method with respect to the TPM method in Kings river, California. On the contrary, (Fiedler, 2003) estimated $-3 \%$ in the Cumberland Plateau (United States). This situation was also reported by (Strauch et al., 2012), who showed variations in model streamflow arround $(+1,5 \%$ in calibration and $+3.5 \%$ in validation) among different rainfall estimation methods (including the TPM). Independently of the method used for weather assignation, the precipitation data are one of the most significant sources of uncertainty of hydrology modelling with SWAT (Aouissi et al., 2013; Rouhani et al., 2009). As other studies have reported and the current research findings support, rainfall datasets tend to drag most of the input model uncertainty along with them. This is the only parameter considered for water input in the model, especially in Mediterranean basins, where the precipitation varies in space and time.

For the soil map, soil clusters for the range from 3 to 50 soil clusters were tested (Figure 5.). The selected set of clusters must present the lowest value between the sum of the normalised mean distance and the normalised DB index (Wehrens and Buydens, 2007). The number of soil clusters with low values for both indices was in the range of 13 to 19 clusters. The comparison between clusters and spatial taxonomic distribution serves as validation of the SOM soil clustering map for SWAT, noting that 16 units is the most suitable number of clusters (Figure 6). Thus, the number of HRUs was reduced from 34,037 to 1,000 HRUs as an improvement proposed by (Luo et al., 2012). This method differs from the use of taxonomic soil units which, in many cases, are not based on soil properties (Burrough, 1983). Using 
this number of soil clusters, a reduced number of HRUs for each sub-basin was obtained, even for the wide extension of the CEA. SOM is a technique increasingly used in water resources for different environmental datasets due to the robustness of the method (Kalteh et al., 2008). However, there is no evidence of the use of SOM in soil clustering for SWAT modelling. Several studies use a similar approach of soil clusters with SOM (Merdun, 2011; Rivera et al., 2015), but not for hydrological modelling purposes. Comparisons between taxonomic units and SOM for the SWAT model are expected to be included in future research.

From the land use cover map series, more than 75,000 different crop rotation possibilities were found in the CEA system during the study period. To include more realistic crop rotations and facilitate management scheduling, the LUU field was updated using the SWAT2009LUU tool, considering only the nine most representative crops, covering in total $86 \%$ of total crops (Table 2). As previously mentioned, the land use update of HRUs employs the (HRU_FR) variable, which allows us to consider the fragmented crop rotation patterns from remote sensing. This setup proposal results in a composite $\mathrm{CN}$ value of the HRUs. From $\mathrm{CN}$ values, patterns associated with row crops, such as potatoes (data not shown), present the highest $\mathrm{CN}$ values (higher runoff potential); this situation is also true for fallow land, while the opposite is true for forage cover (lower runoff potential). HRUs with HRU_FR of fallow land in more than $30 \%$ also present high $\mathrm{CN}$ values, and runoff is increased during rainfall events. Proportional values of $\mathrm{CN}$ by HRU could be provided by the different land use composition of the HRUs.

The model setup for improvement of land use using the SWAT LUU tool results in a CN envelope for the HRUs. The composite value of $\mathrm{CN}$ is related with the amount of surface runoff in a HRU scale. The CEA watershed CN is the average of CNs of the HRUs. The average of CN in CEA is 51.6, similar to mixed forest value of CN2 of the SCS method. In this case, the value of $\mathrm{CN}$ of an HRU is a result of grouped land covers. Normally, hydrologic models provide an insight into runoff causes and a reduced strategy in this way is expected to avoid soil erosion and nutrient transport (Bundy et al., 2008). Nevertheless, a strategy to reduce runoff is difficult to define at HRU level 
with a $\mathrm{CN}$ envelope, but the assessment of the runoff slowdown effect of crop patterns is plausible for decision makers using this approach. To this end, HRU analysis by subbasins is required. Individual land use fragmentation (plot detailed crop rotation) of HRUs is possible by increasing the complexity and computational requirements of the model. Analysis of results in the fragmented HRUs dynamics is not reported in the literature and their analysis is limited to the assessment of global effect at sub-basin scale, due to the complexity and computational requirements to consider individual effect of the land cover over the HRU.

\subsection{SWAT model sensitivity analysis, calibration and validation}

Following Neitsch et al. (2002), a previous analysis was performed to detect the most influential parameters in the streamflow calibration process. This process reveals that 25 parameters are the most sensitive to stream flow changes (Table 5). Parameters related with water dynamics of groundwater recharge (GW_DELAY, REVAPMN, ESCO, SHALLST, GWQMN and ALPHA_BF), runoff (OV_N, CN2 S, SURLAG) and infiltration (SOL_AWC) were respectively the most sensitive in the ranking. Similar parameters for sensitivity ranking were found in other Mediterranean catchments (Galván et al., 2009; Mateus et al., 2014; Salmoral et al., 2017). As in the present study, they also found that the GW_DELAY parameter is one of the most sensitive during the streamflow calibration process. This parameter is related with the lateral flow configuration between the root zone and shallow aquifer connection to the river bed, pointing out the importance of the shallow aquifer and main channel relationship in sub-arid zones. This situation is also reported for other Mediterranean catchments in France (Sellami et al., 2014), Spain (Jimeno-Sáez et al., 2018) or Turkey (Karnez, 2017).

Another sensitive parameter is $\mathrm{CN} 2$ (3th place in the sensitivity ranking). This parameter is related with runoff of the watershed. But the use of composite values of CN per HRUs is complex, as it allows us to include realistic crop rotation, which makes it difficult to define specific measures to manage the runoff per specific land use. Some of the uncertainty related with the runoff component of water balance is based on variability of HRU definition, and analysis of single HRUs is required. 
Daily stream flow performance during calibration (2004-2010) and validation (20112014) is compared in Table 4. According to the performance ratings established by (Moriasi et al., 2007), the VFG monitoring point fits a "very good" class with an NSE of 0.84 (in calibration) and 0.82 (in validation). In the case of LCFG, although the values found are lower, it is still considered a "good" class streamflow performance. Similar values of NSE and $R^{2}$ were also found in several SWAT hydrological calibration studies in Mediterranean watersheds (Dechmi et al., 2012; Galván et al., 2009; Mateus et al., 2014; Salmoral et al., 2017). For the quality model assessment, the PBIAS is considered good if its value is in the $\pm 25 \%$ range (Abbaspour, 2011). The resulting PBIAS for VFG is around $-10 \%$ and for LCFG is around $-18 \%$. Accordingly, model performance is correct, although it underestimates values during the peak flows.

The stream flow calibration and validation shows that VFG (Figure 7) is absolutely influenced by the operation of the reservoirs (Las Cogotas and Pontón Alto). If reservoir operation is not included, no more than an $R^{2}$ of 0.13 could be achieved (series not shown).

It is important to note that the weather regime during the calibration and validation period is not balanced; the calibration was established over three wet years and the validation period was basically during dry years (Figure 8). Moreover, during validation the outflow series show a slight inaccuracy for peak events, when comparing observed and measured flows, resulting in underestimates. During dry years (2009 and 2013) these underestimations are more evident. On the other hand, calibration was settled with wet years (2007, 2008 and 2010). Considering the unbalanced weather regime in the simulation period, the statistical performance indices for validation were expected to be less accurate. Nevertheless, flows are well fitted between simulated and measured LCFG and VFG for calibration and validation. The majority of the unadjusted values are inside the 95PPU band.

Another point to consider is the situation when the model simulates low flow measures, between no flow and $0.4 \mathrm{~m}^{3} / \mathrm{s}$. Nonetheless, the simulated zero flow situations are found in the 95PPU band. Thus, simulated low flows were in part 
responsible for negative values of PBIAS. Further analysis during very low flow days (measured data) is necessary (Bisantino et al., 2010; Skoulikidis et al., 2017). A calibration based on a seasonal scheme is needed (Ricci et al., 2018) and differentiated dynamic baseline flow could provide a strategy to follow (Arnold et al., 1995). Although there are some studies that report very low flows in regulated rivers in Europe (Kirkby et al., 2011), or in Spain (Martinez - Capel et al., 2011; Salmoral et al., 2017), no discussion about this condition related with PBIAS is provided.

It should be noted that LCFG is a gauging station that only depicts $25 \%$ of the Cega upstream watershed. Consequently, downstream hydrology of this point is not gauged, and only indirect evaluation is considered. After the LCFG point is where agricultural water demand increases. Further studies involving a methodology for ungauged watersheds are necessary to validate the Cega downwater calculations of the SWAT model results.

\subsection{Model uncertainty}

Model uncertainty is assessed through the statistical performance indices, P-factor and R-factor. Those indices are correlated and a balance must be achieved during the calibration process. Values of approximately 0.6 for P-factor and between 0.22-0.39

for R-factor, show the model uncertainty degree for the calibrated ranges of parameters. The suggested values are $>0.7$ and $<1.5$ respectively (Abbaspour, 2013). Abbaspour's work noted that for P-factor and R-factor they should be as large as possible, although for large and regulated basins these values could be lower. Largescale and very complex systems (hyper-regulated watersheds) present high variance due to climate conditions. P-factor and R-factor could be targeting close to the range values proposed by Abbaspour in 2004, but these parameters do not necessarily entirely explain the biophysical process. Modellers look for the balance between several factors: the objective function, the function weight, the initial and boundary conditions, and the type and length of measured data used to calibrate (Abbaspour, 2012). Consequently, the parameter-combination band is very complex in large watersheds; other research at daily time scale and large watershed also refers to values in the range of our P-factor and R-factor results (Begou et al., 2016; Roth et al., 
2016). Further study is needed on a sub-basin scale to expand on details to reach higher performance values of the uncertainties.

\subsection{Water balance}

The water balance components (Inflow, outflows and storage volumes) and values are represented in the schema of Figure 9, for each two sub-basins within CEA.

The streamflow/rainfall ratio for regulated catchments is usually lower than in watersheds with natural flow. This statement is borne out in the present study, with a ratio of 0.14 for Eresma-Adaja (regulated) and 0.18 for Cega (unregulated). Similar values were reported for different Mediterranean basins (Merheb et al., 2016). This situation highlights the implications of streamflow regulation in catchments similar to Eresma-Adaja and Cega. Thus, reservoir regulation rules must be seasonally compared to maintain similar runoff ratios between regulated and unregulated stream regimes in these similar catchments. This could be a target to preserve the natural streamflow behaviour in spite of the regulation of large headwater reservoirs.

Streamflow volume is a key element for river authorities. The model estimates a streamflow of $59.4 \mathrm{~mm} / \mathrm{yr}$ for Eresma-Adaja and $82.5 \mathrm{~mm} / \mathrm{yr}$ for Cega. Similar results were reported by the DURERO project (Vicente Gonzalez et al., 2016) for the whole Douro watershed, with a streamflow value of $60.8 \mathrm{~mm} / \mathrm{yr}$. The more accurate water balance in ungauged areas of the watershed provided by the present study could serve as complimentary information for planning purposes at the local scale.

Runoff is a complex component, being the sum of surface runoff and the river baseflow. The latter is the contribution of lateral flow and the groundwater return flow. In this case, the groundwater contribution to the baseflow is higher than the surface runoff, as shown in Table 3. During dry years or dry seasons, the disconnection between riverbed and aquifer is more frequent; this causes very low stream flows. The situation is evident in stream flow series and in the decrease of groundwater level in piezometers. 
SWAT model results show that the CEA system is a deficit watershed. The negative average net balance $(-850.2 \mathrm{~mm} / \mathrm{yr})$ proves it during the simulation period. The comparison of the potential evapotranspiration (ETP=1,192.1 mm/yr) and real evapotranspiration (ET= $341.9 \mathrm{~mm} / \mathrm{yr}$ ) shows a large water deficit (Table 3). The simulation results for CEA indicate on average that only $15.7 \%$ of precipitation is converted into surface flow. This finding indicates that all processes during the soilplant-atmosphere interaction $(>80 \%)$ are quantitatively more relevant than surface flow. For this reason, the vadose zone interface is a key factor in water dynamics in the CEA and merits more in-depth study. For more details on simulation ratios of hydrophysical processes, see supplementary material Table B.

The CEA system is a large sub-basin of the River Douro with a variety of landscapes, which suggest that water balance is not homogeneous in the system. Three zones were defined based on environmental experts' knowledge of landscapes and water management (Figure 10). SWAT model results show that Cega highlands present the highest rainfall in comparison of Eresma-Adaja watershed headwaters. Regarding this difference, it is important to note that stream fluxes are different in volume and water management could be different in middle and lowland areas. In addition, Cega has an absence of regulation infrastructures. Peak flows and flashes were more frequent in the Cega River; these events were reported in communication media during the simulation period. The Eresma-Adaja river tributary zone presents lower rainfall volumes, suggesting that tougher conditions of scarcity could be located in this zone. This suggests that agriculture in this zone is more feasible under a rainfed regime.

In contrast, potential evapotranspiration shows a differentiated trend of higher values in the lowlands and lower in the headwaters. The average ETP of all land covers in the headwater shows a lower value compared to the lowlands, which is due to altitude, predominance of forest (stomatal resistance to ET) and lower temperatures during the spring-summer period. Moreover, real evapotranspiration values in the southern west of Eresma-Adaja are more affected by the recent agricultural development in this area, allocating a pressure in water demand in this area that affects the Eresma-Adaja water availability in the middle and lowlands. 
In general, surface runoff in volume is less than groundwater fluxes in both watersheds (Eresma-Adaja and Cega). However, this relation is true in the lowlands and midland, but different in the headwaters due to water movement through the soil. The roughness of forest and pastures in headwaters for surface runoff slows down the flux. These fluxes enter these shallow soils until they meet rocks and start moving by gravitational forces as lateral flows. This situation limits the deep aquifer recharge in headwaters. The opposite processes of recharge occur in the midlands, where the materials are sandy composites, soil depths are higher and slopes are more flattened. Deep aquifer recharge is higher in the Cega River than in Eresma-Adaja, as higher volumes of lateral flow that comes from the headwaters infiltrates the sandy soils. Lateral flow in headwaters of Eresma-Adaja (south west) could be increased by changing the land use to natural forest covers and pastures. Reservoir and agricultural demand in the Eresma-Adaja headwaters limit the lateral flow and the deep aquifer recharge in the midlands.

Annual water balance shows that there is no water surplus to support new demands, including the expected 18\% irrigation expansion ( $49 \mathrm{hm}^{3} / \mathrm{yr}$ ). Moreover, a tendency of decreasing precipitation is an issue that the watershed must be adapted to. Capture of precipitation peak events with more reservoirs, as suggested by stakeholders, will have a negative impact on stream flow and consequently on aquifer recharge and soil water scarcity of the ecosystem. In sub-arid watersheds, the reservoirs limit riverbed water transfer to aquifer in the downwaters, resulting in a lower water table without capillarity contribution to bottomland crops (Lin, 2011). This effect could be expected in a reduction of groundwater "revap" volume to plants. This situation in CEA could affect "Tierra de Pinares", a valuable ecosystem of conifer forest (900 ha) in watershed midlands that are rooted connected ( $2 \mathrm{~m}$ deep) to the water table.

\subsection{CEA water demand assessment}

According to our results, $86.64 \%$ of water demand for the CEA is allocated to agricultural purposes. Figure 11 shows the average real evapotranspiration (ET) of HRUs during simulation and the area of the dominant rotation crop pattern ( 9 crops). Annual rainfed crops use on average the same water compared to the permanent 
crops, but annual rainfed crops consume this amount of water in only 5-6 months. Furthermore, during the rest of the year when precipitation events are more frequent, fallow land contributes to reduce shallow aquifer recharge. This dynamic is explained by the runoff being privileged in slope land $>5 \%$. During the rotation schema, fallow land is characterised by the lack of surface roughness, causing a quick response with the precipitation-runoff process. This situation prevents a prolonged time of infiltration before the start of surface runoff. Vegetated cover could be used to slow down runoff and increase water use efficiency. Vegetated cover is a strategy to be included in crop rotation schemes, mainly in schemes that include annual rainfed and irrigated row crops for Mediterranean watersheds (Taboada-Castro et al., 2015). Water efficiency can be achieved, but only if annual ET of vegetated cover is approximately $350 \mathrm{~mm} / \mathrm{yr}$. This assertion is based on permanent crop average water consumption. In addition, ET for vegetated cover for inter-annual rotations could be approximately $16 \mathrm{~mm} /$ month during the fall-winter period and $42 \mathrm{~mm} / \mathrm{month}$ during the spring-summer period.

Irrigated crops represent the major water consumption use. A strategy to spatially redistribute crop area in quantity provides a feasible solution to homogenise agricultural water demand. Similar to the situation in rainfed crops, the CEA watershed needs to decrease agricultural irrigation area that uses more than 350 $\mathrm{mm} / \mathrm{yr}$, including crops that demand less water. Focus on barley dominant patterns could be an insight to achieve a balanced water demand. In addition, an economic analysis is also needed to assess a more convenient solution to reduce agricultural water consumption.

Deep aquifer simulated recharge is estimated at $2 \mathrm{~mm} / \mathrm{yr}\left(15.7 \mathrm{hm}^{3} / \mathrm{yr}\right)$. On average, a rate of $25.4 \mathrm{~mm} / \mathrm{yr}\left(196.26 \mathrm{hm}^{3} / \mathrm{yr}\right)$ was used for irrigation during the simulation. Comparing this value with the agricultural water demand established by RBMP $\left(170.42 \mathrm{hm}^{3}\right)$, there is a difference of $26.26 \mathrm{hm}^{3}(3.34 \mathrm{~mm} / \mathrm{yr})$ that could be extracted from aquifers. This finding indicates that possibly shallow aquifers and deep aquifers have been used to extract $26.26 \mathrm{hm}^{3}$, but only $15.7 \mathrm{hm}^{3}$ comes from renewable resources. The overexploitation is more associated with the groundwater bodies of 
"Los Arenales" located downstream, and it is difficult to measure global overdraft due to shared boundaries with other watersheds. Further developments of aquifer recharge could be provided by simulating the entire watershed and aquifer shares with SWAT and MODFLOW.

Most of the groundwater recharge is related to wheat and pasture land cover patterns. In addition to aquifer recharge, groundwater quality tracking in these sandy soils is mandatory. Diffuse pollution of aquifer in this zone is very sensitive, and responsible for the poor status of the water bodies. Fertilisation operation in wheat and pasture improvements needs to be included in further studies on this issue. This situation is also related to diffuse pollution of groundwater bodies due to the fertilisation rates and timing. In SWAT, the CN is relatively easy to manipulate, and any strategy or measure to reduce runoff can be included in the model. Hence, priority strategies for runoff control in potato and barley are needed. See supplementary material Table C.

\section{Conclusions}

CEA, as part of Mediterranean sub-arid catchments with low precipitation rates and accentuated water scarcity during summer, is a fragile ecosystem and some measures are needed to mitigate water resources overexploitation, as commented by other authors (Ricci et al., 2018).

This study shows the ability of SWAT to simulate many complex processes as well as the importance of including detailed land use information to achieve satisfactory model performance. The model can be used to guide water management decisions by stakeholders who have water provision targets to meet, especially in the assigning of more realistic agricultural water demands. Setup improvements assessed through global statistic indices confirm this. Land use and soils are the most important data for the HRUs definition step; any effort to achieve more accurate data and maps will reduce the model uncertainty. The model in a daily time step has closely simulated the observation streamflow. However, calibration of the SWAT model with very low flows is still under study, as intermittent zero flows occurred during simulations with low flows and observation values kept measures under $0.1 \mathrm{~m}^{3} / \mathrm{s}$. 
Flow regulation and infrastructure, such as reservoirs and artificial aquifer recharge, were made to respond to the agricultural demand in the CEA system. These are elements that define a stream's hydric behaviour in meagre flow watersheds such as the CEA. Any improvement to reduce agricultural water demand is a factor that directly increases availability of stream flow. Flow stream increment could be achieved by a redefinition of operating rules for reservoir discharge and reduced volumes for artificial aquifer recharge. All measures addressing the reduction of net irrigation land, deficit irrigation strategies, and less water-demanding crops, among others, are suitable elements to mitigate drought periods with less economic impact.

The main effort to preserve water resources in the CEA under the current water deficit state (very low flows at the outlet) must be directed to soil conservation strategy, due to the importance to water transfer to vegetation and to aquifer recharge. A reduction in water consumption of crop vegetation could contribute directly to increased water availability in stream flows as lateral and return flows. The increase in vegetated covers in fallow areas during (fall-winter) period in slopes $>5 \%$ could help slow down runoff and allow an increase in infiltration time and rates. Thus, the increment of water flux to aquifer recharge could allow the lag time of subsurface flow to streams. Further analysis is needed in headwaters through the application of land use scenarios in this sense.

Finally, many applications are foreseen, such as conducting policy and impact studies, using the model for climate and LUC studies and analysing the implications of intersub-basin transfers, among others.

\section{Acknowledgements}

Funding for this work was provided by MINECO № PCIN-2014-080 and № PCIN2014-085. The support provided by CEIGRAM (Centro de Estudios e Investigación para la Gestión de Riesgos Agrarios y Medioambientales) and IMDEA Water Institute is fully appreciated. Comments and suggestions provided by three anonymous reviewers significantly contributed to improving the flow and overall understanding of the manuscript. 


\section{References}

Abbaspour, K.C., 2013. SWAT-CUP 2012: SWAT calibration and uncertainty programs-a user manual. Eawag Dübendorf, Switz. 103.

Abbaspour, K.C., 2011. Swat-Cup2: SWAT Calibration and Uncertainty Programs Manual Version 2, Department of Systems Analysis, Integrated Assessment and Modelling (SIAM).

Abbaspour, K.C., Johnson, C.A., van Genuchten, M.T., 2004. Estimating Uncertain Flow and Transport Parameters Using a Sequential Uncertainty Fitting Procedure. Vadose Zo. J. 3, 1340-1352.

Abbaspour, K.C., Rouholahnejad, E., Vaghefi, S., Srinivasan, R., Yang, H., Kløve, B., 2015. A continental-scale hydrology and water quality model for Europe: Calibration and uncertainty of a high-resolution large-scale SWAT model. J. Hydrol. 524, 733-752. https://doi.org/https://doi.org/10.1016/j.jhydrol.2015.03.027

Antequera, C.M., Gamo, R.M., Rubio, J.M., 2014. Estudios preliminares para el diseño de una instalación de recarga artificial en la zona oriental del acuífero de "El Carracillo, Segovia." Boletín geológico y Min. 125, 187-202.

Aouissi, J., Benabdallah, S., Chabaâne, Z.L., Cudennec, C., 2013. Sensitivity analysis of SWAT model to the spatial rainfall distribution and watershed subdivision in streamflow simulations in the Mediterranean context: A case study in the Joumine watershed. Tunisia, in: 2013 5th International Conference on Modeling, Simulation and Applied Optimization (ICMSAO). pp. 1-6. https://doi.org/10.1109/ICMSA0.2013.6552706

Arnold, J., Srinivasan, R., Muttiah, R., Williams, J., 1998. Large area hydrologic modeling and assessment - Part 1: Model development. J. Am. Water Resour. Assoc. 34, 73-89.

Arnold, J.G., Allen, P.M., Muttiah, R., Bernhardt, G., 1995. Automated Base Flow Separation and Recession Analysis Techniques. Ground Water 33, 1010-1018. https://doi.org/10.1111/j.1745-6584.1995.tb00046.x

Ashraf Vaghefi, S., Mousavi, S.J., Abbaspour, K.C., Srinivasan, R., Arnold, J.R., 2015. Integration of hydrologic and water allocation models in basin-scale water resources management considering crop pattern and climate change: Karkheh River Basin in Iran. Reg. Environ. Chang. 15, 475-484. https://doi.org/10.1007/s10113-013-0573-9

Begou, J., Jomaa, S., Benabdallah, S., Bazie, P., Afouda, A., Rode, M., 2016. Multi-Site Validation of the SWAT Model on the Bani Catchment: Model Performance and Predictive Uncertainty. Water 8, 178. https://doi.org/10.3390/w8050178

Benedini, M., Tsakiris, G., 2013. Model Calibration and Verification BT - Water Quality Modelling for Rivers and Streams, in: Benedini, M., Tsakiris, G. (Eds.), . Springer Netherlands, Dordrecht, pp. 223-229. https://doi.org/10.1007/978-94-007-5509-3_18

Bisantino, T., Gentile, F., Milella, P., Liuzzi, G.T., 2010. Effect of Time Scale on the Performance of Different Sediment Transport Formulas in a Semiarid Region. J. Hydraul. Eng. 136, 5661. https://doi.org/10.1061/(ASCE)HY.1943-7900.0000125

Bundy, L.G., Mallarino, A.P., Good, L.W., 2008. 12. Field-Scale Tools for Reducing Nutrient 
Losses to Water Resources.

Burrough, P.A., 1983. Multiscale sources of spatial variation in soil. I. The application of fractal concepts to nested levels of soil variation. J. soil Sci. 34, 577-597.

Calbó, J., 2010. Possible Climate Change Scenarios with Specific Reference to Mediterranean Regions BT - Water Scarcity in the Mediterranean: Perspectives Under Global Change, in: Sabater, S., Barceló, D. (Eds.), . Springer Berlin Heidelberg, Berlin, Heidelberg, pp. 1-13. https://doi.org/10.1007/698_2009_28

CHD, 2015. Plan Hidrológico de la Demarcación Hidrográfica del Duero 2015-2021.

Davies, D.L., Bouldin, D.W., 1979. A cluster separation measure. IEEE Trans. Pattern Anal. Mach. Intell. 224-227.

Dechmi, F., Burguete, J., Skhiri, A., 2012. SWAT application in intensive irrigation systems: model modification, calibration and validation. J. Hydrol. 470, 227-238.

Dodds, F., Bartram, J., 2016. The water, food, energy and climate Nexus: Challenges and an Agenda for action. Routledge.

European Comission, 2012. Report on the Review of the European Water Scarcity and Droughts Policy.

European Environment Agency, 2015. The european environment : state and outlook 2015 : synthesis report. Copenhagen European Environment Agency, Copenhagen.

EUROSTAT, 2017. Annual freshwater abstraction by source and sector in Europe.

Fiedler, F., 2003. Simple, Practical Method for Determining Station Weights Using Thiessen Polygons and Isohyetal Maps. J. Hydrol. Eng. 8, 219-221. https://doi.org/10.1061/(ASCE)1084-0699(2003)8:4(219)

Galván, L., Olías, M., de Villarán, R.F., Santos, J.M.D., Nieto, J.M., Sarmiento, A.M., Cánovas, C.R., 2009. Application of the SWAT model to an AMD-affected river (Meca River, SW Spain). Estimation of transported pollutant load. J. Hydrol. 377, 445-454.

Gassman, P.W., Reyes, M.R., Green, C.H., Arnold, J.G., 2007. The Soil and Water Assessment Tool: Historical Development, Applications, and Future Research Directions. Iowa State Univ.

Giorgi, F., Lionello, P., 2008. Climate change projections for the Mediterranean region. Glob. Planet. Change 63, 90-104. https://doi.org/https://doi.org/10.1016/j.gloplacha.2007.09.005

Grieco, A., Pacella, M., Blaco, M., 2017. On the application of text clustering in Engineering Change process. Procedia CIRP 62, 187-192.

Guzinski, R., Kass, S., Huber, S., Bauer-Gottwein, P., Jensen, I.H., Naeimi, V., Doubkova, M., Walli, A., Tottrup, C., 2014. Enabling the use of earth observation data for integrated water resource management in Africa with the water observation and information system. Remote Sens. 6, 7819-7839.

Hoff, H., Iceland, C., Kuylenstierna, J., te Velde, D.W., 2012. Managing the Water-Land-Energy 
Nexus for Sustainable Development. Chronicle 49.

IGME, 2009. Identificación y caracterización de la interrelación que se presenta entre aguas subterráneas, cursos fluviales, descargas por manantiales, zonas húmedas y otros ecosistemas naturales de especial interés hídrico. Demarcación Hidrográfica 021 Duero. SISTEM.

IGME, 2008. Integración de las masas de agua subterranea en el modelo de gestión de la cuenca hidrográfica del Duero. Determinación de los parámetros de simulación (coeficientes de agotamiento).

Jimeno-Sáez, P., Senent-Aparicio, J., Pérez-Sánchez, J., Pulido-Velazquez, D., 2018. A comparison of SWAT and ANN models for daily runoff simulation in different climatic zones of peninsular Spain. Water (Switzerland) 10, <xocs:firstpage xmlns:xocs="" />. https://doi.org/10.3390/w10020192

Kalogeropoulos, K., Chalkias, C., Pissias, E., Karalis, S., 2011. Application of the SWAT model for the investigation of reservoirs creation BT - Advances in the Research of Aquatic Environment: Volume 2, in: Lambrakis, N., Stournaras, G., Katsanou, K. (Eds.), . Springer Berlin Heidelberg, Berlin, Heidelberg, pp. 71-79. https://doi.org/10.1007/978-3-64224076-8_9

Kalteh, A.M., Hjorth, P., Berndtsson, R., 2008. Review of the self-organizing map (SOM) approach in water resources: Analysis, modelling and application. Environ. Model. Softw. 23, 835-845. https://doi.org/https://doi.org/10.1016/j.envsoft.2007.10.001

Karnez, E., 2017. Modeling Agricultural Land Management to Improve Understanding of Nitrogen Leaching in an Irrigated Mediterranean Area in Southern Turkey, in: Sagir, H. (Ed.), . IntechOpen, Rijeka, p. Ch. 7. https://doi.org/10.5772/65809

Kaur, R., Singh, O., Srinivasan, R., Das, S.N., Mishra, K., 2004. Comparison of a Subjective and a Physical Approach for Identification of Priority Areas for Soil and Water Management in a Watershed - A Case Study of Nagwan Watershed in Hazaribagh District of Jharkhand, India. Environ. Model. Assess. 9, 115-127. https://doi.org/10.1023/B:ENM0.0000032094.92482.6f

Kim, K.B., Kwon, H.-H., Han, D., 2018. Exploration of warm-up period in conceptual hydrological modelling. J. Hydrol. 556, 194-210.

Kirkby, M., Gallart, F., Kjeldsen, T., Irvine, B., Froebrich, J., Porto, A., De Girolamo, A., Team, the, 2011. Classifying low flow hydrological regimes at a regional scale. Hydrol. Earth Syst. Sci. 15, 3741. https://doi.org/10.5194/hess-15-3741-2011

Laurent, F., Ruelland, D., 2011. Assessing impacts of alternative land use and agricultural practices on nitrate pollution at the catchment scale. J. Hydrol. 409, 440-450.

Lin, H., Wheeler, D., Bell, J., Wilding, L., 2005. Assessment of soil spatial variability at multiple scales. Ecol. Modell. 182, 271-290.

Lin, Q., 2011. Influence of dams on river ecosystem and its countermeasures. J. Water Resour. Prot. 3, 60.

Luo, Y., Ficklin, D.L., Zhang, M., 2012. Approaches of soil data aggregation for hydrologic 
simulations. J. Hydrol. 464-465, 467-476.

https://doi.org/10.1016/j.jhydrol.2012.07.036

Martinez - Capel, F., Belmar, O., Velasco, J., 2011. Hydrological classification of natural flow regimes to support environmental flow assessments in intensively regulated Mediterranean rivers, Segura River Basin (Spain) 47. https://doi.org/10.1007/s00267011-9661-0

Mateus, M., Almeida, C., Brito, D., Neves, R., 2014. From Eutrophic to Mesotrophic: Modelling Watershed Management Scenarios to Change the Trophic Status of a Reservoir. Int. J. Environ. Res. Public Health 11, 3015-3031. https://doi.org/10.3390/ijerph110303015

Mauro, D.L., G., A.J., Raghavan, S., 2005. Effect of GIS data quality on small watershed stream flow and sediment simulations. Hydrol. Process. 19, 629-650. https://doi.org/10.1002/hyp.5612

Merdun, H., 2011. Self-organizing map artificial neural network application in multidimensional soil data analysis. Neural Comput. Appl. 20, 1295-1303. https://doi.org/10.1007/s00521-010-0425-1

Merheb, M., Moussa, R., Abdallah, C., Colin, F., Perrin, C., Baghdadi, N., 2016. Hydrological response characteristics of Mediterranean catchments at different time scales: a metaanalysis. Hydrol. Sci. J. 61, 2520-2539.

Morán-Tejeda, E., Ceballos-Barbancho, A., Llorente-Pinto, J.M., 2010. Hydrological response of Mediterranean headwaters to climate oscillations and land-cover changes: The mountains of Duero River basin (Central Spain). Glob. Planet. Change 72, 39-49.

Moriasi, D.N., Arnold, J.G., Van Liew, M.W., Bingner, R.L., Harmel, R.D., Veith, T.L., 2007. Model evaluation guidelines for systematic quantification of accuracy in watershed simulations. Trans. ASABE 50, 885-900.

Moriasi, D.N., Rossi, C.G., Arnold, J.G., Tomer, M.D., 2012. Evaluating hydrology of the Soil and Water Assessment Tool (SWAT) with new tile drain equations. J. soil water Conserv. 67, 513-524.

Narsimlu, B., Gosain, A., Chahar, B., 2013. Assessment of Future Climate Change Impacts on Water Resources of Upper Sind River Basin, India Using SWAT Model. An Int. J. - Publ. Eur. Water Resour. Assoc. 27, 3647-3662. https://doi.org/10.1007/s11269-013-0371-7

Nash, J.E., Sutcliffe, J. V, 1970. River flow forecasting through conceptual models part I - A discussion of principles. J. Hydrol. 10, 282-290. https://doi.org/https://doi.org/10.1016/0022-1694(70)90255-6

Neitsch, S.L., Arnold, J.G., Kiniry, J.R. e a1, Srinivasan, R., Williams, J.R., 2002. Soil and water assessment tool user's manual version 2000. GSWRL Rep. 202.

Neitsch, S.L., Arnold, J.G., Kiniry, J.R., Srinivasan, R., Williams, J.R., 2005. Soiland Water Assessment Tool, Theorical Documentation Version 2005. Grassland Soiland Water Research Laboratory. Agric. Res. Serv. Blackl. Res. Center-Texas Agric. Exp. Station. USA.

Pai, N., Saraswat, D., 2011. SWAT2009_LUC: A Tool to Activate the Land Use Change Module in SWAT 2009. Trans. ASABE v. 54, 1649-1658-2011 v.54 no.5. 
Pande, G., Al-Mashidani, B.B., Lal, B.B., 1978. TECHNIQUE FOR THE DETERMINATION OF AREAL AVERAGE RAINFALL. J Phys D Appl Phys 23, 445-453.

Psomas, A., Dagalaki, V., Panagopoulos, Y., Konsta, D., Mimikou, M., 2016. Sustainable Agricultural Water Management in Pinios River Basin Using Remote Sensing and Hydrologic Modeling. Procedia Eng. 162, 277-283.

https://doi.org/https://doi.org/10.1016/j.proeng.2016.11.059

Rafael, M., Àngel, R.-A.M., Carlos, G.J., Joan, A., 2010. El Niño Southern Oscillation and climate trends impact reservoir water quality. Glob. Chang. Biol. 16, 2857-2865. https://doi.org/10.1111/j.1365-2486.2010.02163.x

Ricci, G.F., De Girolamo, A.M., Abdelwahab, O.M.M., Gentile, F., 2018. Identifying sediment source areas in a Mediterranean watershed using the SWAT model. L. Degrad. Dev. 29, 1233-1248. https://doi.org/10.1002/ldr.2889

Rivera, D., Sandoval, M., Godoy, A., 2015. Exploring soil databases: a self-organizing map approach. Soil Use Manag. 31, 121-131. https://doi.org/10.1111/sum.12169

Roth, V., Nigussie, T., Lemann, T., 2016. Model parameter transfer for streamflow and sediment loss prediction with SWAT in a tropical watershed. Environ. Earth Sci. 75, 1-13. https://doi.org/10.1007/s12665-016-6129-9

Rouhani, H., Willems, P., Feyen, J., 2009. Effect of watershed delineation and areal rainfall distribution on runoff prediction using the SWAT model. Hydrol. Res. 40, 505-519.

Salmoral, G., Willaarts, B.A., Garrido, A., Guse, B., 2017. Fostering integrated land and water management approaches: Evaluating the water footprint of a Mediterranean basin under different agricultural land use scenarios. Land use policy 61, 24-39. https://doi.org/https://doi.org/10.1016/j.landusepol.2016.09.027

Seeboonruang, U., 2012. A statistical assessment of the impact of land uses on surface water quality indexes. J. Environ. Manage. 101, 134-142.

https://doi.org/https://doi.org/10.1016/j.jenvman.2011.10.019

Seeger, M., 2007. Uncertainty of factors determining runoff and erosion processes as quantified by rainfall simulations. CATENA 71, 56-67. https://doi.org/https://doi.org/10.1016/j.catena.2006.10.005

Sellami, H., Jeunesse, I., Benabdallah, S., Baghdadi, N., Vanclooster, M., 2014. Uncertainty analysis in model parameters regionalization: a case study involving the SWAT model in Mediterranean catchments (Southern France). Hydrol. Earth Syst. Sci. 18, 2393. https://doi.org/10.5194/hess-18-2393-2014

Skoulikidis, N.T., Sabater, S., Datry, T., Morais, M.M., Buffagni, A., Dörflinger, G., Zogaris, S., Del Mar Sánchez-Montoya, M., Bonada, N., Kalogianni, E., Rosado, J., Vardakas, L., De Girolamo, A.M., Tockner, K., 2017. Non-perennial Mediterranean rivers in Europe: Status, pressures, and challenges for research and management. Sci. Total Environ. 577, 1-18. https://doi.org/10.1016/j.scitotenv.2016.10.147

Spaaks, J.H., Bouten, W., 2013. Resolving structural errors in a spatially distributed hydrologic model using ensemble Kalman filter state updates. Hydrol. Earth Syst. Sci. 17, 34553472. 
Strauch, M., Bernhofer, C., Koide, S., Volk, M., Lorz, C., Makeschin, F., 2012. Using precipitation data ensemble for uncertainty analysis in SWAT streamflow simulation. J. Hydrol. 414415, 413-424. https://doi.org/https://doi.org/10.1016/j.jhydrol.2011.11.014

Taboada-Castro, M.M., Rodríguez-Blanco, M.L., Palleiro, L., Taboada-Castro, M.T., 2015. Soil crusting and surface runoff in agricultural land in Galicia (NW Spain). Spanish J. Soil Sci. 5.

Tharme, R.E., 2003. A global perspective on environmental flow assessment: emerging trends in the development and application of environmental flow methodologies for rivers. River Res. Appl. 19, 397-441. https://doi.org/10.1002/rra.736

Thiessen, A.H., 1911. Precipitation averages for large areas. Mon. Weather Rev. 39, 10821089.

Tripathi, M.P., Panda, R.K., Raghuwanshi, N.S., 2003. Identification and Prioritisation of Critical Sub-watersheds for Soil Conservation Management using the SWAT Model. Biosyst. Eng. 85, 365-379. https://doi.org/10.1016/S1537-5110(03)00066-7

Ullrich, A., Volk, M., 2009. Application of the Soil and Water Assessment Tool (SWAT) to predict the impact of alternative management practices on water quality and quantity. Agric. Water Manag. 96, 1207-1217. https://doi.org/10.1016/j.agwat.2009.03.010

Vicente Gonzalez, D.J., Rodríguez Sinobas, L., Garrote de Marcos, L., Sánchez Calvo, R., 2016. Application of the System of Environmental Economic Accounting for Water SEEAW to the Spanish part of the Duero basin: lessons learned. Sci. Total Environ. ISSN 0048-9697, 2016-09, Vol. 563-4.

Wagner, P.D., Fiener, P., Wilken, F., Kumar, S., Schneider, K., 2012. Comparison and evaluation of spatial interpolation schemes for daily rainfall in data scarce regions. J. Hydrol. 464465, 388-400. https://doi.org/10.1016/j.jhydrol.2012.07.026

Wang, G., Mang, S., Cai, H., Liu, S., Zhang, Z., Wang, L., Innes, J.L., 2016. Integrated watershed management: evolution, development and emerging trends. J. For. Res. 27, 967-994. https://doi.org/10.1007/s11676-016-0293-3

Wehrens, R., Buydens, L.M.C., 2007. Self- and Super-organizing Maps in R: The kohonen Package. J. Stat. Softw. 21. https://doi.org/10.18637/jss.v021.i05

Zhao, A., Zhu, X., Liu, X., Pan, Y., Zuo, D., 2016. Impacts of land use change and climate variability on green and blue water resources in the Weihe River Basin of northwest China. CATENA 137, 318-327.

https://doi.org/https://doi.org/10.1016/j.catena.2015.09.018 
Table 1. Model input data sources for Cega-Eresma-Adaja (CEA) SWAT baseline model.

\begin{tabular}{|c|c|c|}
\hline Data & Description/properties & Source of data \\
\hline $\begin{array}{l}\text { Digital Elevation } \\
\text { model (DEM) }\end{array}$ & $25 \mathrm{~m}$ resolution. Map used to define two slope classes $0-3$ and $>3 \%$ & $\begin{array}{l}\text { MDT25, LiDAR-PNOA by } @ \\
\text { Instituto Geográfico Nacional }\end{array}$ \\
\hline Flow gauges & $\begin{array}{l}\text { Daily discharge (2004-2014) for } 2 \text { points: Valdestillas VFG (Adaja river) } \\
\text { and Lastras de Cuellar LCFG (Cega river) }\end{array}$ & CHD - Douro's RBA; CEDEX \\
\hline Reservoirs & $\begin{array}{l}\text { Three reservoirs. Las Cogotas }\left(58,6 \mathrm{hm}^{3}\right) \text {, Pontón Alto }\left(7,4 \mathrm{hm}^{3}\right) \text { and } \\
\text { Serones }\left(6,3 \mathrm{hm}^{3}\right)\end{array}$ & CHD - Douro's RBA \\
\hline Land use & $\begin{array}{l}20 \mathrm{~m} \text { resolution, } 31 \text { basic land-cover categories. Including } 18 \text { different } \\
\text { crops. }\end{array}$ & ITACyL, 2013 \\
\hline Soil characteristics & $\begin{array}{l}16 \text { soil types were determined using } 407 \text { soil samples and introducing } \\
\text { (Saulniers et al, 1997) soil depth empirical model to obtain a total of } 92 \\
\text { soil different units. }\end{array}$ & ITACyL, 2013 \\
\hline Weather data & $\begin{array}{l}\text { Data for } 2004 \text { - 2014. Precipitation, daily maximum and minimum } \\
\text { temperature, daily global solar radiation, surface wind speed, daily mean } \\
\text { relative humidity. }\end{array}$ & AEMET \\
\hline $\begin{array}{l}\text { Agricultural } \\
\text { management practices }\end{array}$ & $\begin{array}{l}\text { Surveys from ITACyL for INFORIEGO services. Database for irrigation } \\
\text { districts with free access. }\end{array}$ & ITACyL, 2013 \\
\hline
\end{tabular}


Table 2. Cega-Eresma-Adaja (CEA) main crop rotation patterns during simulation period

\begin{tabular}{ccccc}
\hline Crop dominant & Number of crop patterns & Percentage & Area [ha] & $\mathrm{CN}^{1}$ \\
\hline Barley & 19.762 & $26,11 \%$ & 128.354 & 64,56 \\
Wheat & 16.992 & $22,45 \%$ & 109.940 & 63,13 \\
Fallow & 7.493 & $9,90 \%$ & 48.481 & 80,07 \\
Sunflower & 7.183 & $9,49 \%$ & 46.474 & 67,79 \\
Other cereals & 5.480 & $7,24 \%$ & 35.455 & 64,07 \\
Horticulture & 3.096 & $4,09 \%$ & 20.029 & 67,00 \\
Bean legumes & 2.006 & $2,65 \%$ & 12.977 & 67,80 \\
Forrages & 1.809 & $2,39 \%$ & 11.704 & 35,00 \\
Peas & 1.082 & $1,43 \%$ & 7.003 & 67,00 \\
Others crops* & 10.786 & $14,25 \%$ & 150.010 & $----*$ \\
\hline
\end{tabular}

${ }^{1}$ Average calibrated of Curve Number $(\mathrm{CN})$ value for different crops

*Other crops include different land covers (forest and 17 other crops with different $\mathrm{CN}$ ). 
Table 3. Water balance components for Eresma-Adaja and Cega watersheds with SWAT model.

\begin{tabular}{|c|c|c|c|c|c|c|c|c|c|c|c|}
\hline \multirow[b]{2}{*}{ Type } & \multirow{2}{*}{$\begin{array}{r}\text { Period } \\
\text { Hydrologic } \\
\text { Year } \\
\text { year type } \\
\end{array}$} & \multirow[b]{2}{*}{$\begin{array}{c}2005 \\
\text { Average }\end{array}$} & \multicolumn{3}{|c|}{ Calibration } & \multirow[b]{2}{*}{$\begin{array}{l}2009 \\
\text { dry }\end{array}$} & \multirow[b]{2}{*}{$\begin{array}{l}2010 \\
\text { wet }\end{array}$} & \multicolumn{2}{|c|}{ Validation } & \multirow[b]{2}{*}{$\begin{array}{l}2013 \\
\text { dry }\end{array}$} & \multirow[b]{2}{*}{$\begin{array}{c}\text { Simulation } \\
\text { mean values }\end{array}$} \\
\hline & & & $\begin{array}{c}2006 \\
\text { Average }\end{array}$ & $\begin{array}{l}2007 \\
\text { wet }\end{array}$ & $\begin{array}{l}2008 \\
\text { wet }\end{array}$ & & & $\begin{array}{c}2011 \\
\text { average }\end{array}$ & $\begin{array}{c}2012 \\
\text { average }\end{array}$ & & \\
\hline \multirow{11}{*}{$\begin{array}{l}\text { Eresma- } \\
\text { Adaja }\end{array}$} & Precipitation & 368.2 & 424.0 & 491.0 & 583.6 & 326.5 & 485.8 & 374.1 & 386.4 & 303.5 & 415.9 \\
\hline & ETP & 1346.8 & 1272.1 & 1162.4 & 1154.3 & 1315.1 & 1193.8 & 1298.0 & 1301.1 & 690.5 & 1192.7 \\
\hline & Deficit & 978.6 & 848.1 & 671.4 & 570.7 & 988.6 & 708.0 & 923.9 & 914.7 & 387.0 & 776.8 \\
\hline & ET & 269.5 & 413.8 & 409.3 & 389.7 & 332.2 & 363.6 & 362.1 & 294.0 & 219.2 & 339.3 \\
\hline & Flow & 29.8 & 49.4 & 68.4 & 81.5 & 59.9 & 59.5 & 57.0 & 33.9 & 95.2 & 59.4 \\
\hline & VFG-Flow ${ }_{\text {obs }}$ & 29.31 & 48.54 & 67.2 & 80.09 & 58.89 & 58.44 & 56.04 & 33.28 & 80.79 & 57.0 \\
\hline & Surface runoff & 13.2 & 15.4 & 24.1 & 25.9 & 10.2 & 16.8 & 13.6 & 14.4 & 11.3 & 16.1 \\
\hline & Baseflow & 16.6 & 34 & 44.3 & 55.6 & 49.7 & 42.7 & 43.4 & 19.5 & 83.9 & 43.3 \\
\hline & $\begin{array}{l}\text { Deep aquifer } \\
\text { recharge }\end{array}$ & 3.05 & 3.51 & 4.07 & 4.83 & 2.70 & 4.03 & 3.1 & 3.2 & 2.51 & 2.81 \\
\hline & Soil storage & 13.45 & 15.48 & 17.93 & 21.31 & 11.92 & 17.74 & 13.66 & 14.11 & 11.08 & 15.19 \\
\hline & $\begin{array}{l}\text { SAV + Reservoir } \\
\text { regulation }\end{array}$ & 52.4 & -58.19 & -8.7 & 86.26 & -80.22 & 40.94 & -61.76 & 41.19 & -24.49 & -0.8 \\
\hline \multirow{11}{*}{ Cega } & Precipitation & 366.7 & 473.5 & 498.4 & 583.5 & 386.5 & 558.2 & 373.0 & 404.3 & 376.0 & 446.7 \\
\hline & ETP & 1345.2 & 1248.1 & 1133.5 & 1127.4 & 1303.9 & 1176.3 & 1334.7 & 1333.0 & 717.3 & 1191.1 \\
\hline & Deficit & 978.5 & 774.6 & 635.1 & 543.9 & 917.4 & 618.1 & 961.7 & 928.7 & 341.3 & 744.3 \\
\hline & ET & 274.7 & 420.9 & 425.9 & 394.9 & 325.1 & 371.5 & 355.0 & 319.4 & 235.2 & 346.9 \\
\hline & Flow & 34.4 & 64.0 & 90.9 & 106.5 & 86.6 & 118.7 & 60.9 & 42.9 & 137.7 & 82.5 \\
\hline & LCFG-Flow ${ }_{\mathrm{obs}}$ & 144.42 & 269.14 & 382.02 & 447.77 & 363.89 & 498.76 & 255.74 & 180.11 & 507.83 & 338.85 \\
\hline & Surface runoff & 12.3 & 15.6 & 20.2 & 20.7 & 11.2 & 17.3 & 11.6 & 12.6 & 12.7 & 14.9 \\
\hline & Baseflow & 22.1 & 48.4 & 70.7 & 85.8 & 75.4 & 101.4 & 49.3 & 30.3 & 125 & 67.6 \\
\hline & $\begin{array}{l}\text { Deep aquifer } \\
\text { recharge }\end{array}$ & 4.23 & 5.46 & 5.75 & 6.73 & 4.46 & 6.44 & 4.3 & 4.66 & 4.33 & 5.15 \\
\hline & Soil storage & 13.39 & 17.29 & 15.56 & 21.31 & 14.11 & 20.39 & 13.62 & 14.76 & 13.73 & 16.31 \\
\hline & SAV & 39.28 & -34.15 & -39.71 & 54.06 & -43.77 & 41.17 & 0.08 & 65.48 & 122.74 & 78.34 \\
\hline
\end{tabular}

Values in [mm/yr]

Note: VFG-Flow obs: observed flow at Valdestillas Flow gauge; LCFG-Flow obs: observed flow at Lastras de Cuellar Flow gauge; ETP: potential evapotranspiration; ET: evapotranspiration; Flow: simulated flow; Surface runoff: simulated surface runoff; SAV: Shallow aquifer variation. 
Table 4. Daily calibration and validation statistics for SWAT model.

\begin{tabular}{ccccc}
\hline \multirow{2}{*}{ Statistical Index } & \multicolumn{2}{c}{ VFG } & \multicolumn{2}{c}{ LCFG } \\
\cline { 2 - 5 } & Calibration & Validation & Calibration & Validation \\
\hline $\mathrm{R}^{2}$ & $\begin{array}{c}0.86 \\
\text { (very good) }\end{array}$ & $\begin{array}{c}0.85 \\
\text { (very good) }\end{array}$ & $\begin{array}{c}0.69 \\
\text { (good) }\end{array}$ & $\begin{array}{c}0.67 \\
\text { (good) }\end{array}$ \\
\hline \multirow{2}{*}{$\mathrm{NS}$} & $\begin{array}{c}0.84 \\
\text { (very good) }\end{array}$ & $\begin{array}{c}0.82 \\
\text { (very good) }\end{array}$ & $\begin{array}{c}0.65 \\
\text { (good) }\end{array}$ & $\begin{array}{c}0.61 \\
\text { (good) }\end{array}$ \\
\hline \multirow{2}{*}{ bR $^{2}$} & 0.70 & 0.61 & 0.70 & 0.61 \\
\hline PBIAS & -10.8 & -9.1 & $-15,8$ & -18.6 \\
(good) & $($ very good) & (good) & (good) \\
\hline \multirow{2}{*}{ KGE } & 0.84 & 0.86 & 0.70 & 0.71 \\
\hline \multirow{2}{*}{ p_factor } & 0.63 & 0.61 & 0.57 & 0.53 \\
\hline \multirow{2}{*}{ R_factor } & 0.39 & 0.37 & 0.22 & 0.21 \\
\hline
\end{tabular}


Table 5. Summary of calibration parameters implemented with SUFI2.

\begin{tabular}{|c|c|c|c|c|c|c|c|}
\hline Parameter & Definition & Units & $\begin{array}{l}\text { Default } \\
\text { range }\end{array}$ & $\begin{array}{l}\text { Calibrated } \\
\text { value }\end{array}$ & $\begin{array}{l}\text { Sensitivity } \\
\text { Ranking }\end{array}$ & $t$-stat & P-value \\
\hline GW_DELAY.gw & Groundwater delay & days & $30-450$ & 218.79 & 1 & 6.043 & 0.000 \\
\hline OV_N.hru & $\begin{array}{l}\text { Manning's " } n \text { " value for } \\
\text { overland flow }\end{array}$ & na & $0.01-30$ & 2.13 & 2 & -3.168 & 0.002 \\
\hline CN2.mgt & $\begin{array}{l}\text { SCS runoff curve number for } \\
\text { moisture condition } 2\end{array}$ & na & $(-0.2)-0.2$ & 0.32 & 3 & -2.903 & 0.004 \\
\hline REVAPMN.gw & $\begin{array}{l}\text { Threshold depth of water in the } \\
\text { shallow aquifer for "REVAP" to } \\
\text { occur }\end{array}$ & $\mathrm{mm}$ & $0-500$ & 534.74 & 4 & -1.421 & 0.159 \\
\hline SOL_AWC.sol & $\begin{array}{l}\text { Available water capacity of the } \\
\text { soil layer }\end{array}$ & $\mathrm{mm} / \mathrm{mm}$ & $0-0.5$ & 0.54 & 5 & -1.291 & 0.200 \\
\hline SURLAG.bsn & Surface runoff lag time & days & $0-24$ & 10.41 & 6 & -1.039 & 0.301 \\
\hline ESCO.hru & $\begin{array}{l}\text { Soil evaporation compensation } \\
\text { factor }\end{array}$ & na & $0-1$ & 0.23 & 7 & 0.994 & 0.324 \\
\hline SHALLST.gw & $\begin{array}{l}\text { Initial depth of water in the } \\
\text { shallow aquifer }\end{array}$ & $\mathrm{mm}$ & $0-1000$ & 612.32 & 8 & -0.952 & 0.344 \\
\hline GWQMN.gw & $\begin{array}{l}\text { Threshold depth of water in the } \\
\text { shallow aquifer required for } \\
\text { return flow to occur }\end{array}$ & $\mathrm{mm}$ & $0-5000$ & 1.06 & 9 & -0.925 & 0.357 \\
\hline ALPHA_BF.gw & Baseflow alpha factor & days & $0-1$ & 0.057 & 10 & -0.884 & 0.379 \\
\hline LAT_TIME.hru & Lateral flow travel time & days & $0-180$ & 160.84 & 11 & -0.843 & 0.401 \\
\hline SLSOIL.hru & $\begin{array}{l}\text { Slope length for lateral } \\
\text { subsurface flow }\end{array}$ & $\mathrm{mm}$ & $0-150$ & 65.97 & 12 & -0.723 & 0.472 \\
\hline HRU_SLP.hru & Average slope steepness & $\mathrm{m} / \mathrm{m}$ & $0-0.6$ & 0.28 & 13 & 0.688 & 0.494 \\
\hline CH_K2.rte & $\begin{array}{l}\text { Effective hydraulic conductivity } \\
\text { in main channel alluvium }\end{array}$ & $\mathrm{mm} / \mathrm{hr}$ & $0-500$ & 181.17 & 14 & -0.636 & 0.527 \\
\hline SOL_z.sol & $\begin{array}{l}\text { Depth from soil surface to } \\
\text { bottom of layer }\end{array}$ & $\mathrm{mm}$ & $0-1000$ & 776.57 & 15 & 0.544 & 0.610 \\
\hline CH_K1.sub & $\begin{array}{l}\text { Effective hydraulic conductivity } \\
\text { in tributary channel alluvium }\end{array}$ & $\mathrm{mm} / \mathrm{hr}$ & $0-300$ & 24.10 & 16 & -0.607 & 0.546 \\
\hline SLSUBBSN.hru & Average slope length & $\mathrm{m}$ & $10-150$ & 137.96 & 17 & -0.595 & 0.553 \\
\hline CANMX.hru & Maximum canopy storage & $\mathrm{mm}$ & $0-100$ & 57.62 & 18 & 0.387 & 0.699 \\
\hline CH_N2.rte & $\begin{array}{l}\text { Manning's " } n \text { " value for the } \\
\text { main channel }\end{array}$ & na & $0-0.3$ & 0.10 & 19 & 0.387 & 0.700 \\
\hline CH_N1.sub & $\begin{array}{l}\text { Manning's "n" value for the } \\
\text { tributary channels }\end{array}$ & na & $0.01-30$ & 5.54 & 20 & -0.377 & 0.707 \\
\hline EVRCH.bsn & $\begin{array}{l}\text { Reach evaporation adjustment } \\
\text { factor }\end{array}$ & na & $0.5-1$ & 0.85 & 21 & -0.179 & 0.857 \\
\hline GW_REVAP.gw & $\begin{array}{l}\text { Groundwater "REVAP" } \\
\text { coefficient }\end{array}$ & na & $0-0.3$ & 0.08 & 22 & 0.166 & 0.868 \\
\hline RCHRG_DP.gw & $\begin{array}{l}\text { Deep aquifer percolation } \\
\text { fraction }\end{array}$ & fraction & $0-1$ & 0.20 & 23 & -0.076 & 0.939 \\
\hline EPCO.hru & $\begin{array}{l}\text { Plant uptake compensation } \\
\text { factor }\end{array}$ & na & $0-1$ & 0.39 & 24 & 0.041 & 0.967 \\
\hline PLAPS.sub & Precipitation lapse rate & $\mathrm{mm} / \mathrm{km}$ & $0-100$ & 77.58 & 25 & -0.016 & 0.987 \\
\hline
\end{tabular}




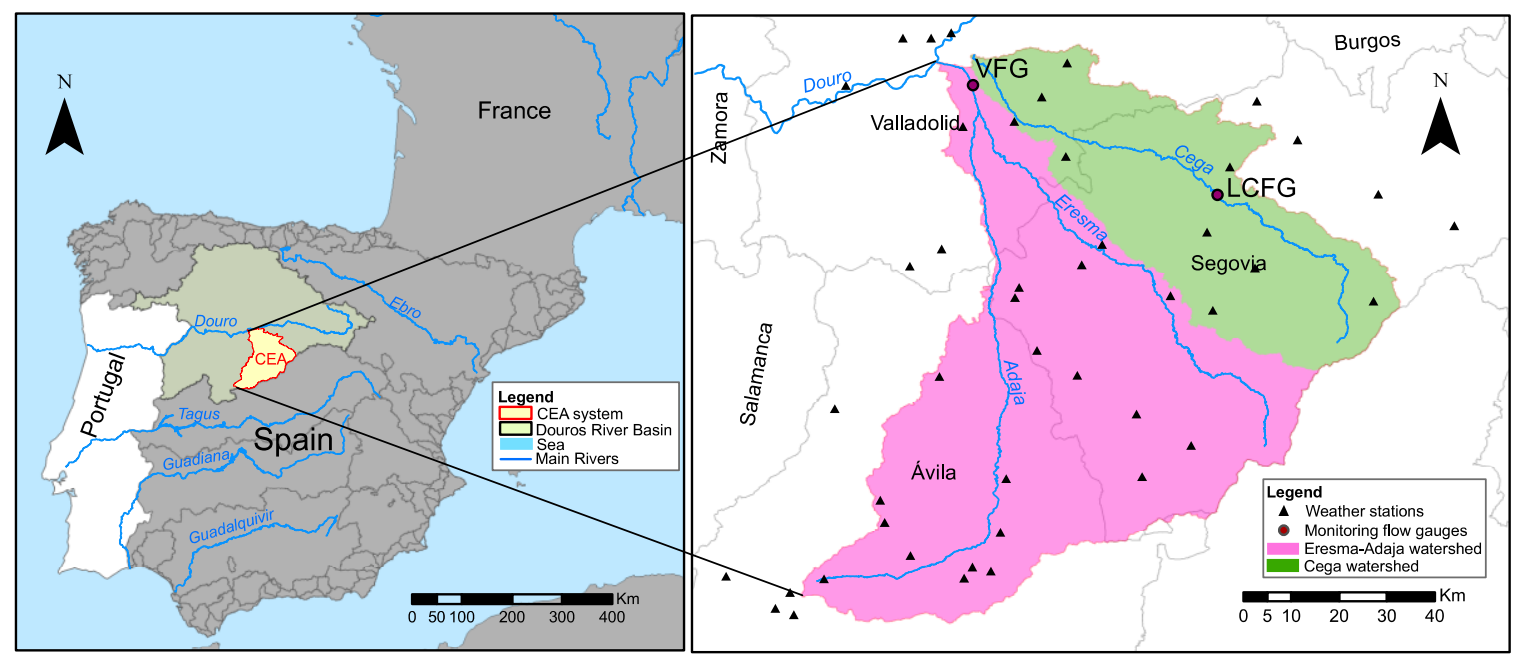

Figure 1. Location of the study area in Douro's River basin, river network and flow gauges. 


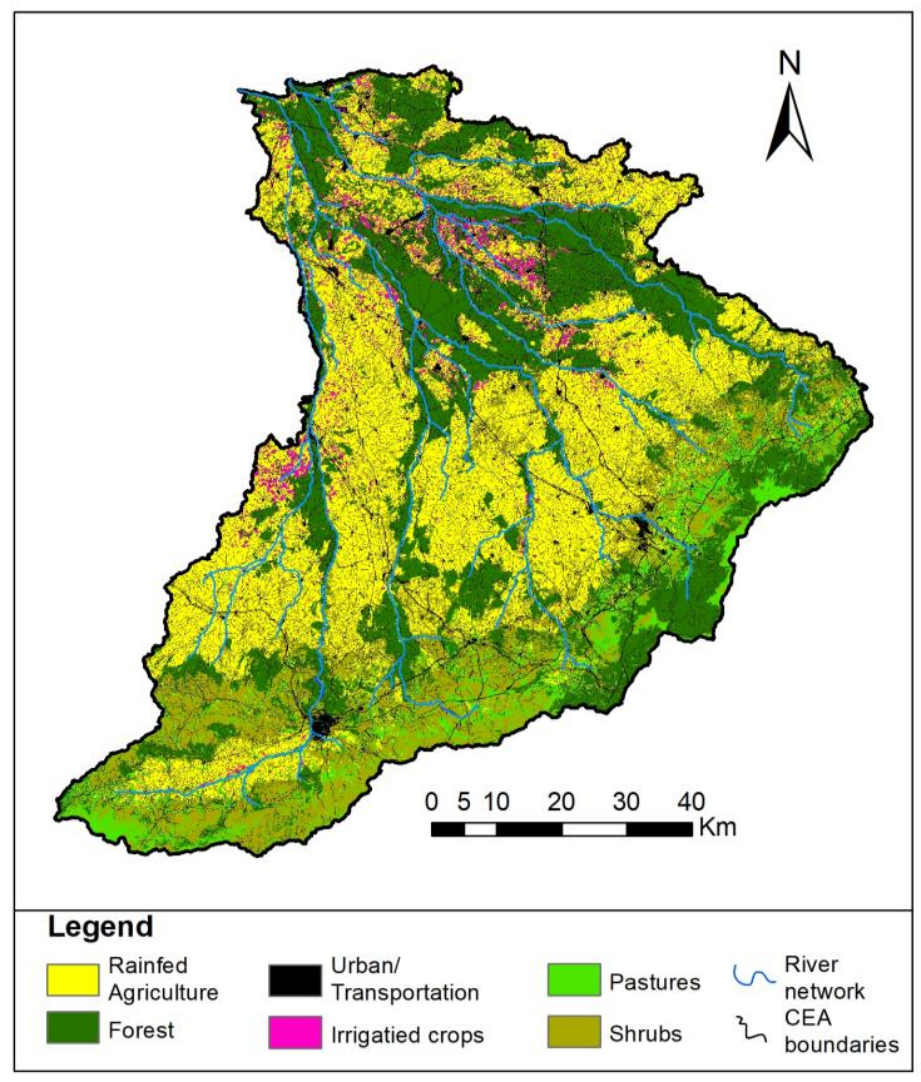

Figure 2. Land use of CEA system 


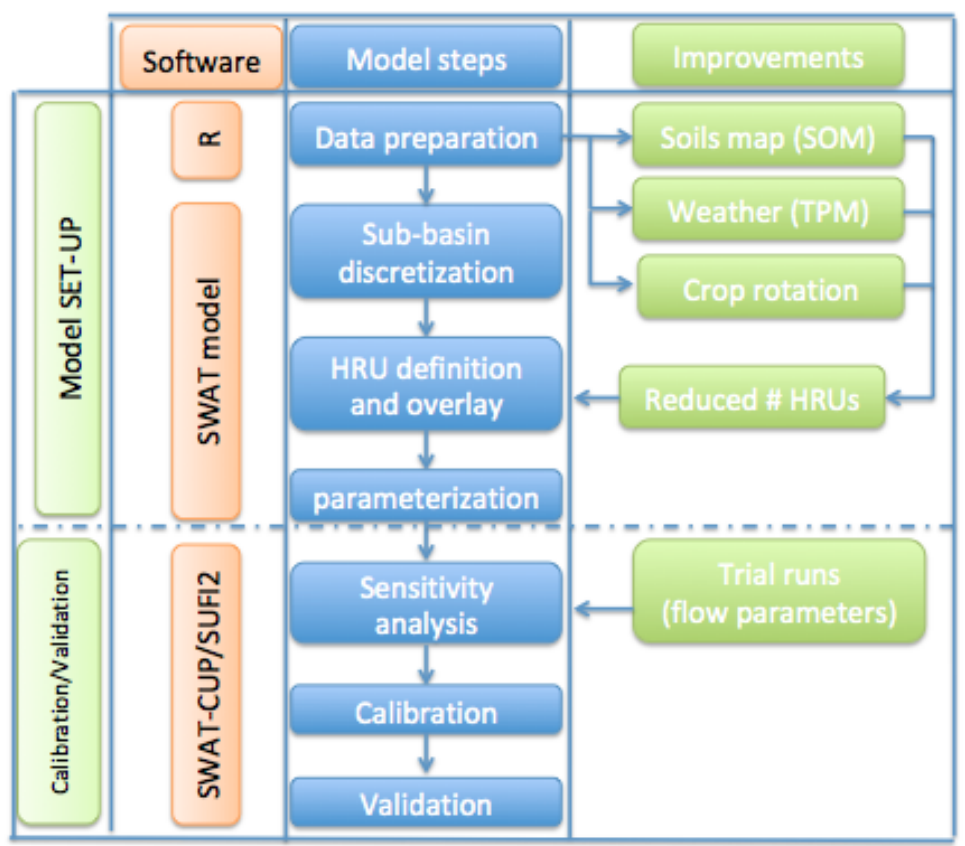

Figure 3. SWAT model development flowchart main steps and implemented software. 


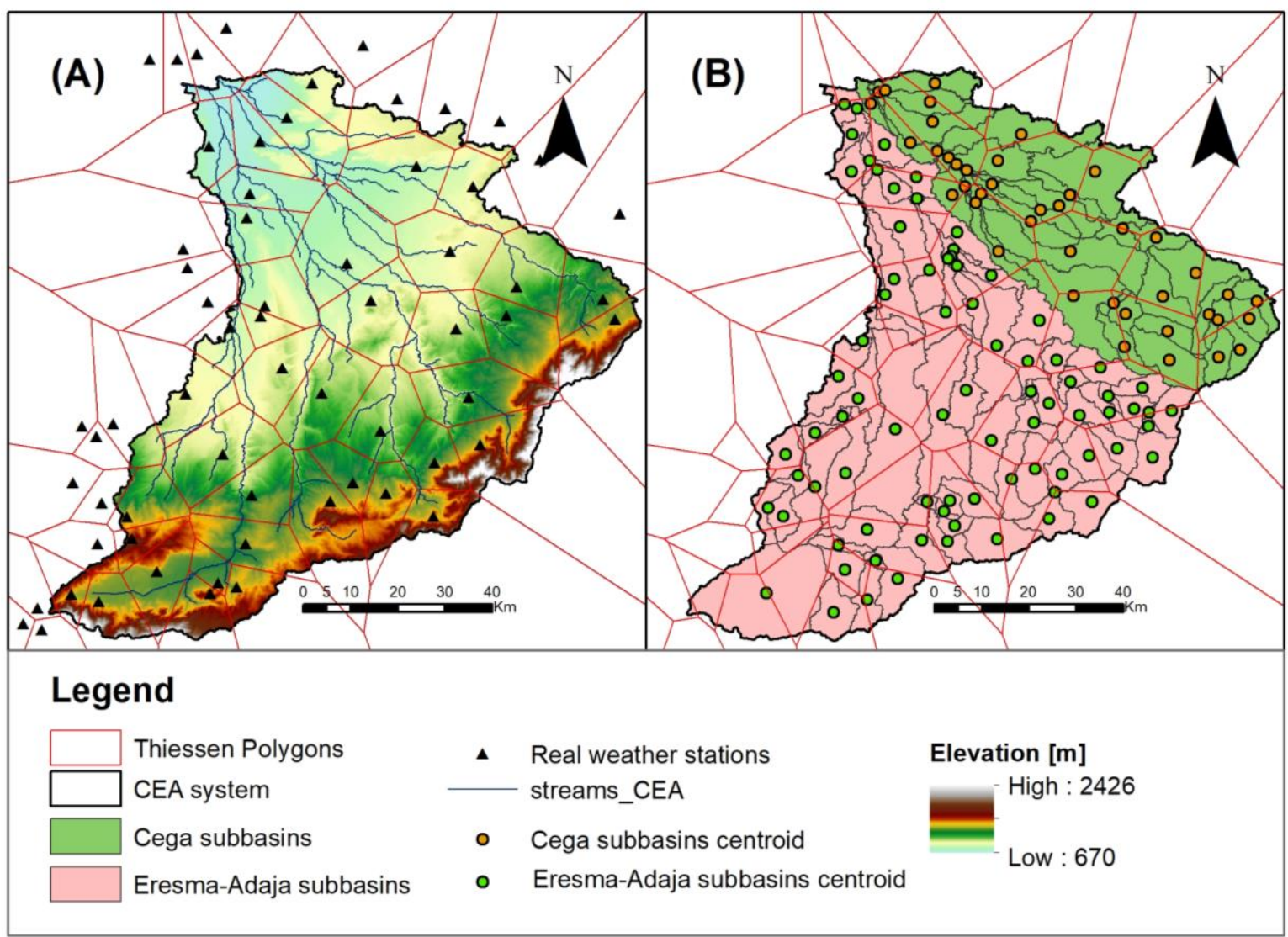

Figure 4. Weather data definition to CEA subbasins (A) and Thiessen Polygon Method (TPM) to define weather stations for SWAT model (B). Weather stations assigned by subbasin centroid for SWAT model. 


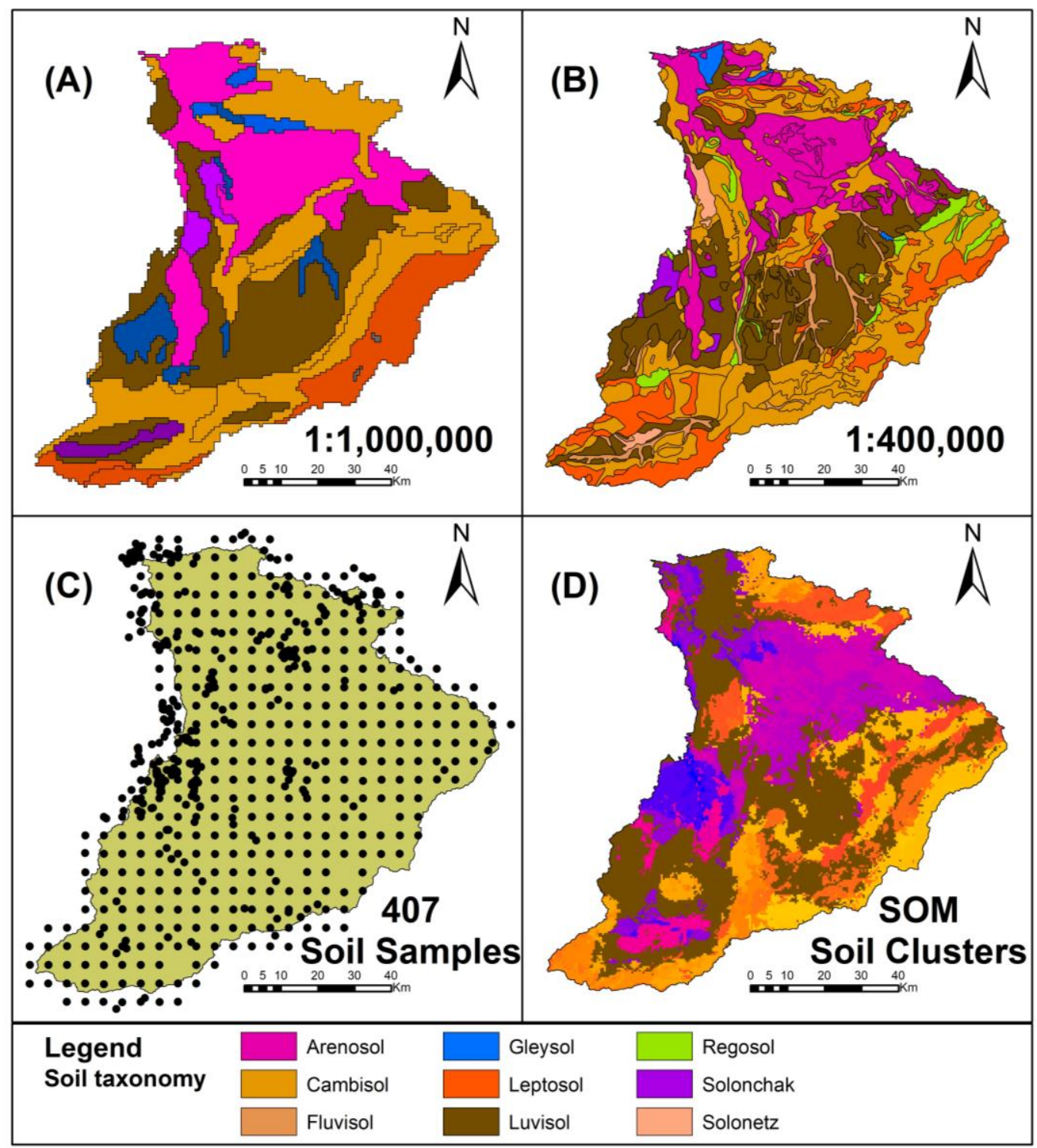

Figure 5. Soil and land use classifications in Cega-Eresma-Adaja (CEA) watershed, colors show the soil taxonomy relationship between the different scales. (A) FAO (HWSD) Soil map at scale 1:1,000,000 (14 soil units), (B) Soils map of CyL at scale 1:400,000 (291 soil units), (C) ITACyL soil samples sites, (D) SOM soil clusters (16 clusters) with depth differentiation (92 soil units) at $20 \mathrm{~m}$ resolution. 


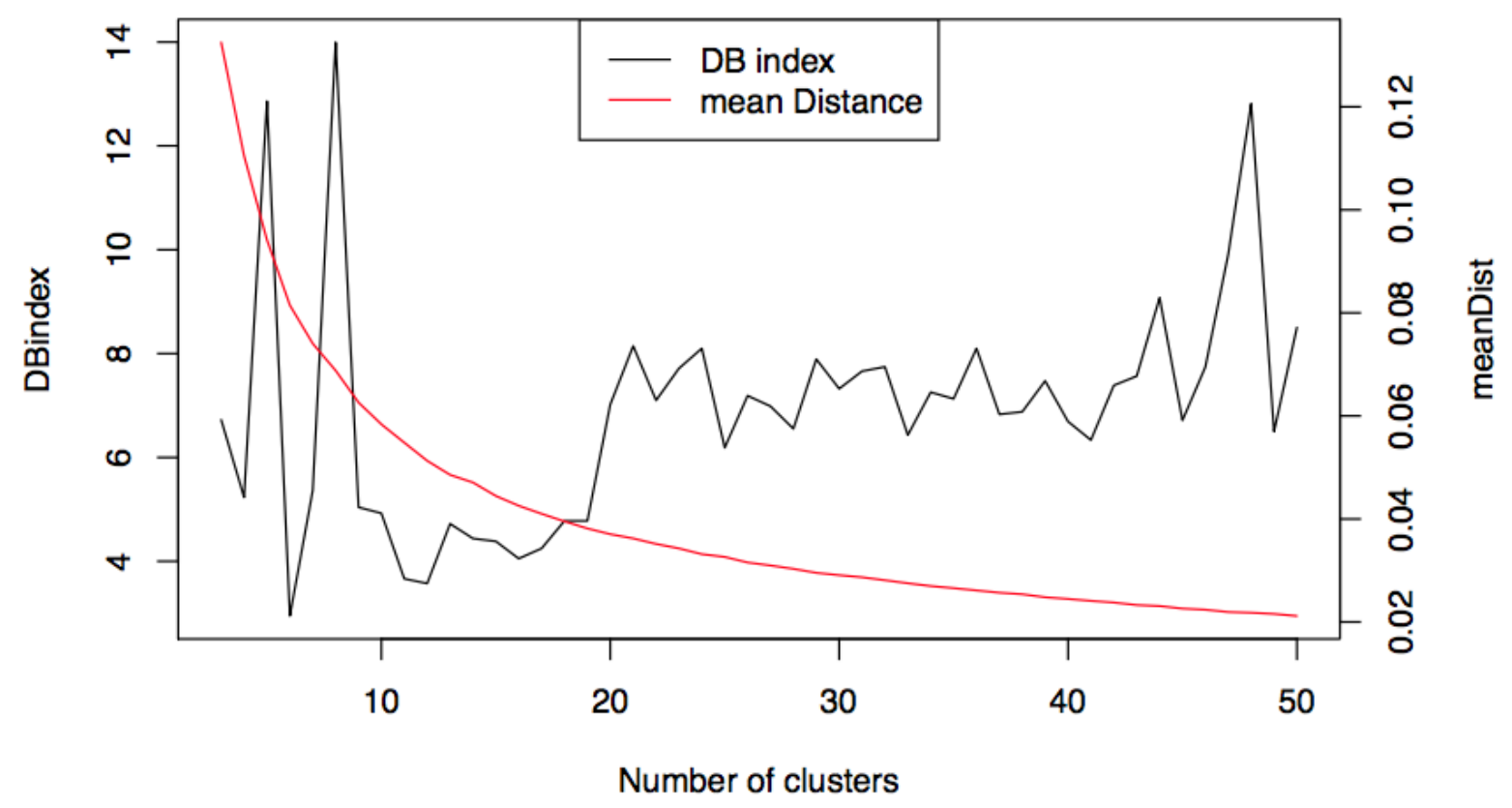

Figure 6. Comparison of D-B index and mean Distance of soil map clustering in Self-Organizing Map (SOM) procedure. 

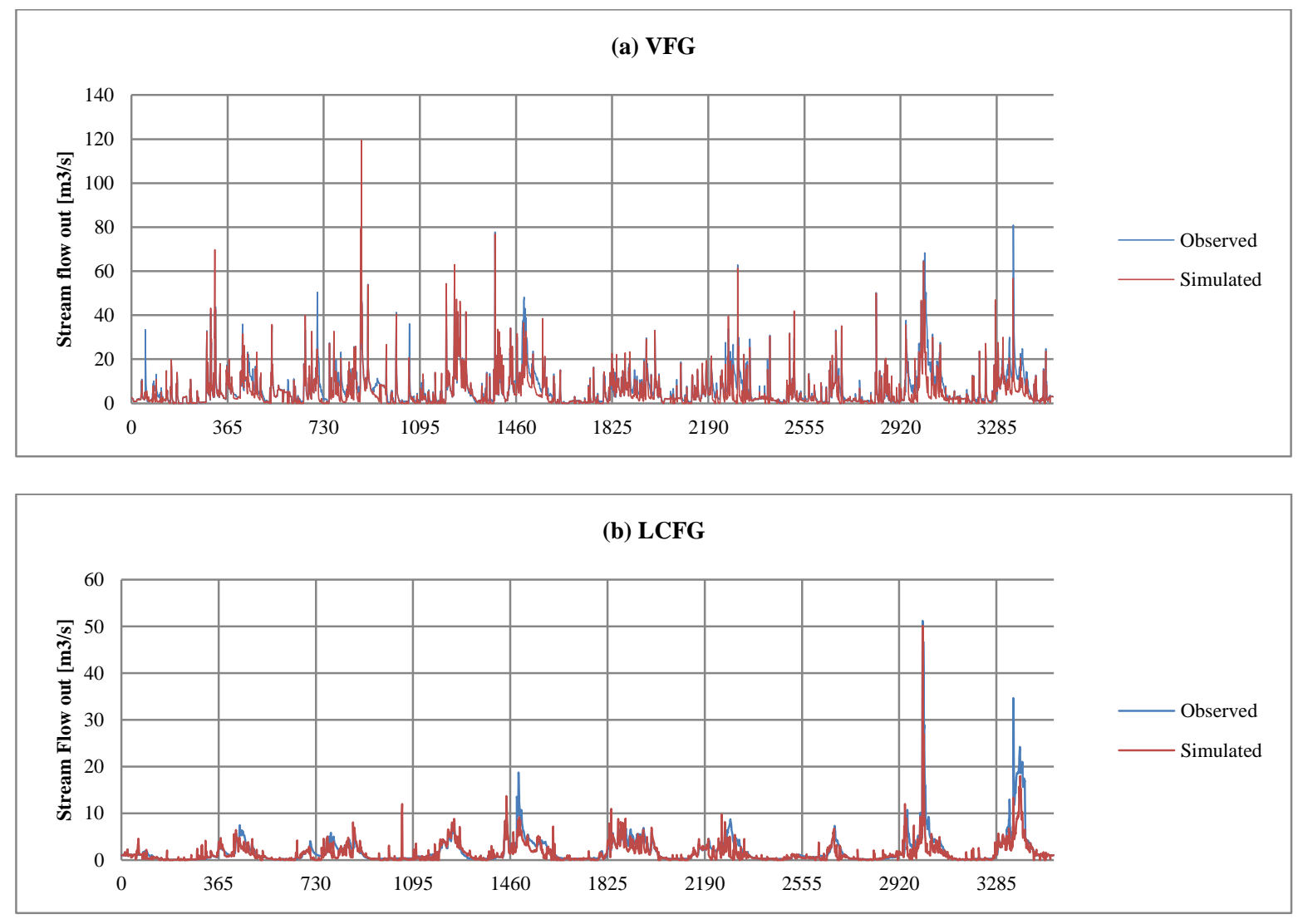

Figure 7. Observed and simulated daily streamflow using SWAT model for (a) VFG, (b) LCFG 

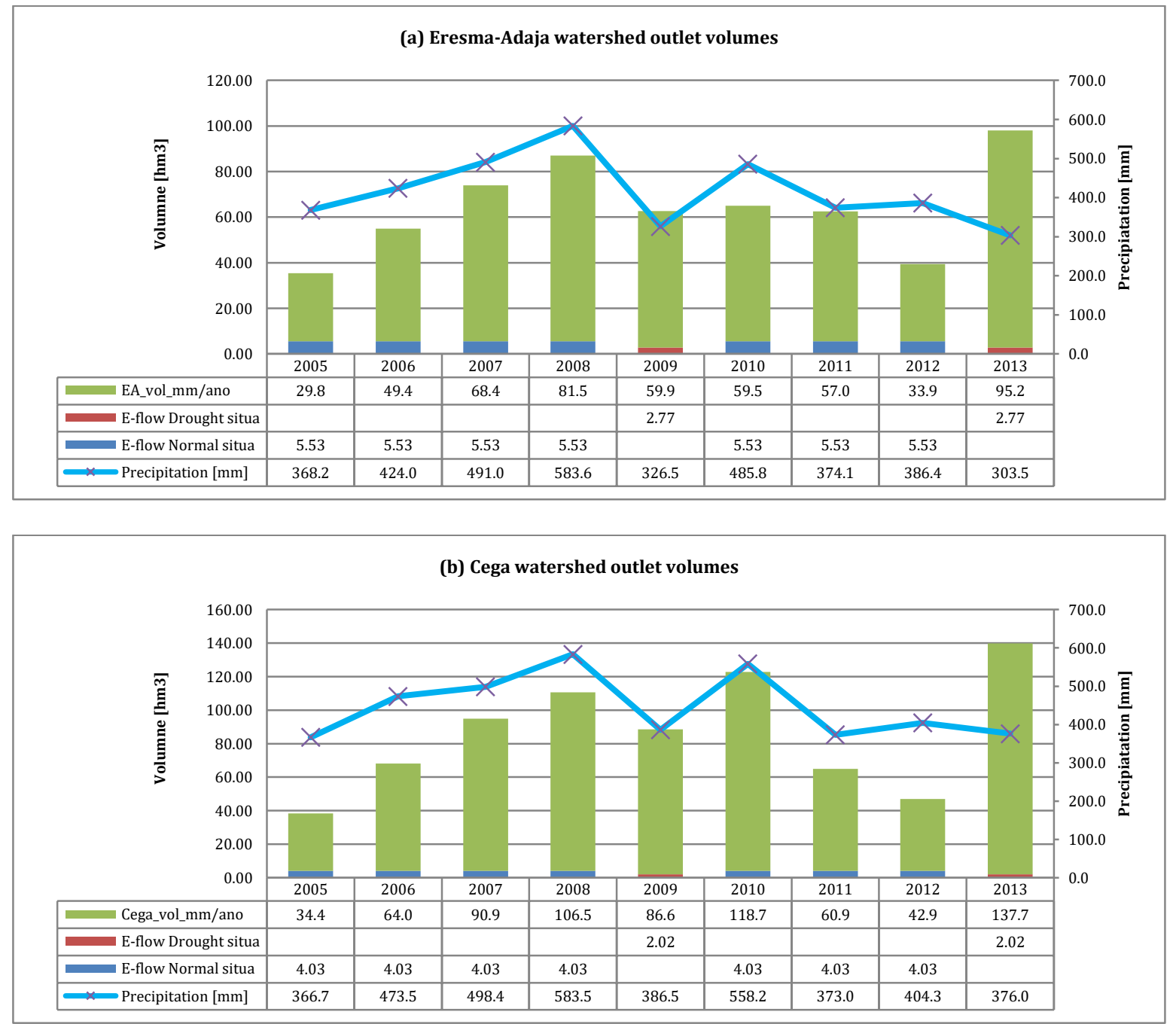

Figure 8. Yearly watershed total volumes outlet and ecological flow in comparison to precipitation for (a) Eresma0Adaj watershed and (b) Cega watershed. 


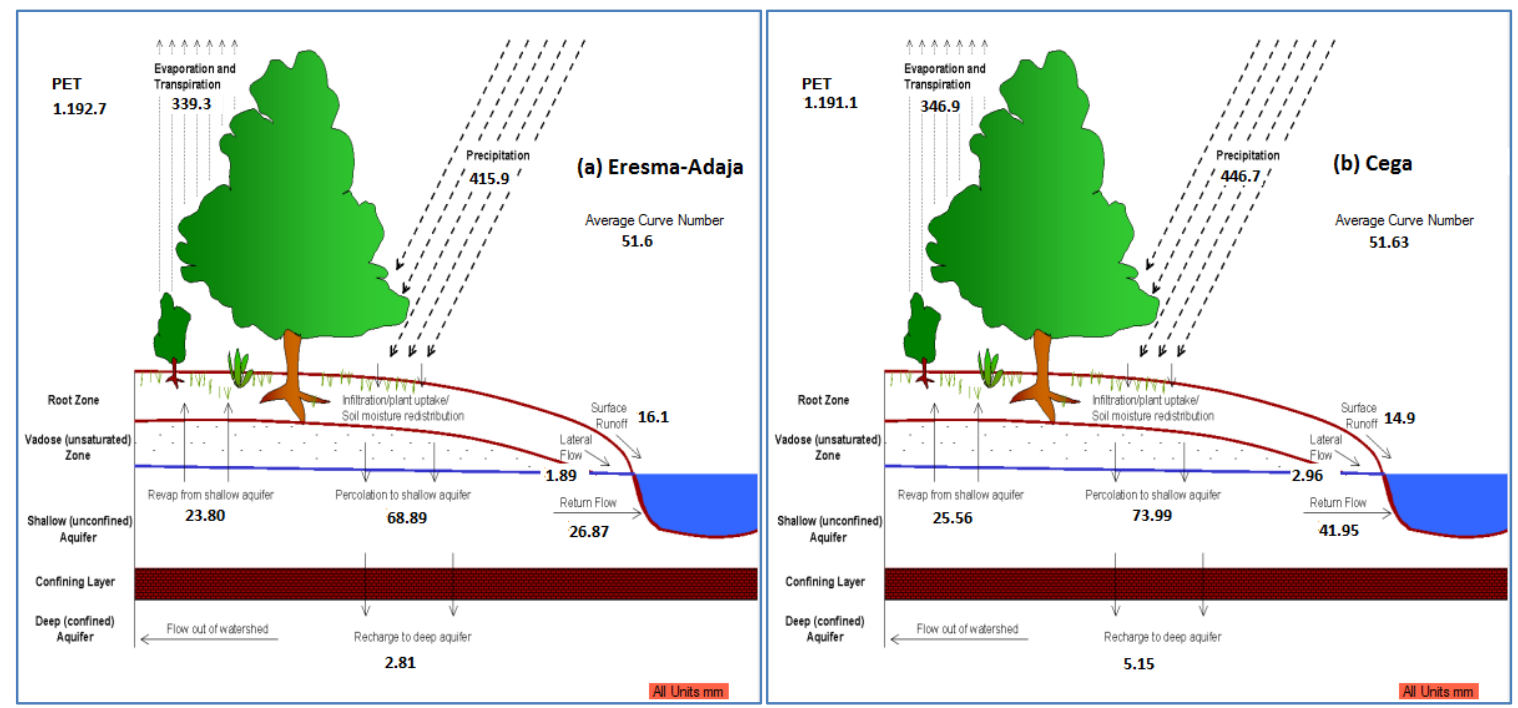

Figure 9. The SWAT model balance components of CEA subbasins. Cega river (left) and EA(Eresma-Adaja) (right). 


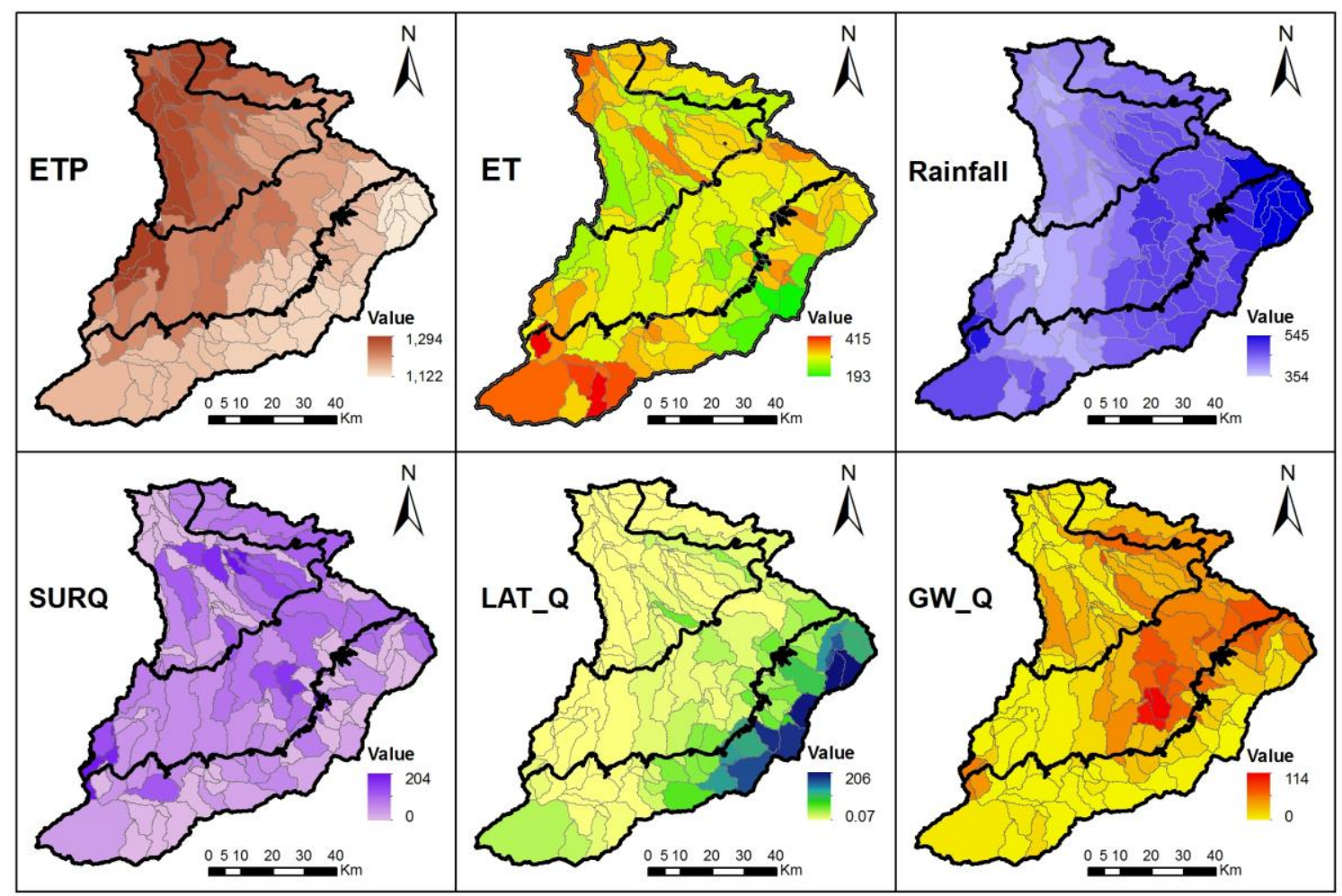

Figure 10. Mean annual water balance components of CEA subbasins. Values in [mm]. ET (real evapotranspiration), ETP (potential evapotranspiration), SURQ (surface runoff), LAT_Q(lateral flow), GW_Q(ground water recharge). Headwaters in the south and low lands in north-west. 


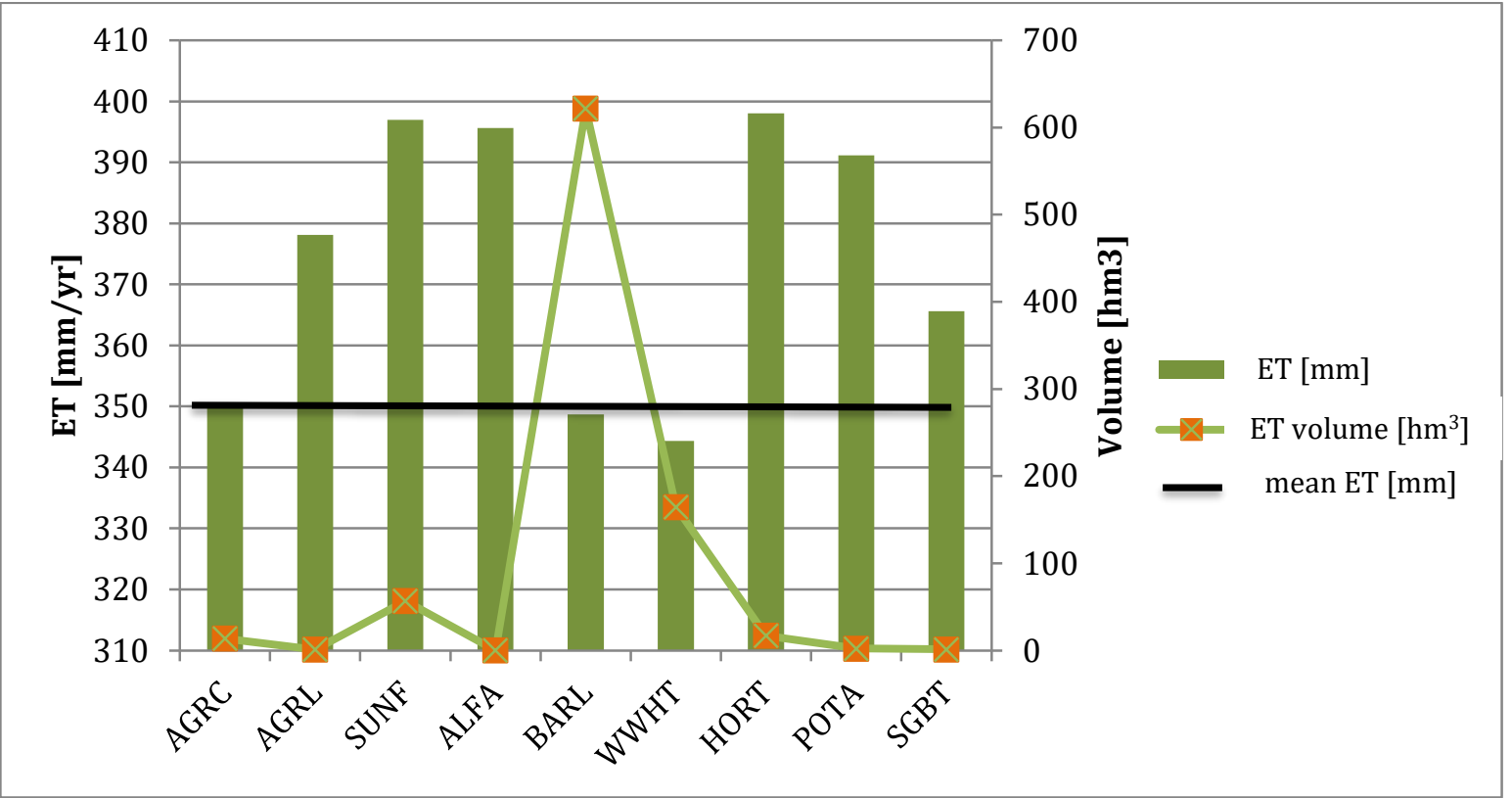

2 Figure 11. Summary of land use water demand in Cega-Eresma-Adaja (CEA) watershed simulated 3 with SWAT: Evapotranspiration (ET), mean ET and water volume (Volume). 


\section{Supporting Information}

20

21 Table A. Detailed crop management operations of Cega-Eresma-Adaja (CEA) case study

\begin{tabular}{|c|c|c|c|c|c|c|c|c|}
\hline Land use crop & $\begin{array}{l}\text { SWAT Landuse } \\
\text { code }\end{array}$ & Planting Date & Tillage operation name & Tillage date & $\begin{array}{c}\text { Auto- } \\
\text { Fertilization } \\
\text { initial date }\end{array}$ & $\begin{array}{c}\text { Fertilizer } \\
\text { composition }\end{array}$ & $\begin{array}{c}\text { Fertilizer total } \\
\text { amount }\end{array}$ & $\begin{array}{c}\text { Harvest } \\
\text { operation date }\end{array}$ \\
\hline \multirow{3}{*}{ Winter Wheat } & \multirow{3}{*}{ WWHT } & \multirow{3}{*}{ 08-dec } & Fallplow & 03-dec & \multirow{3}{*}{ 12-oct } & \multirow{3}{*}{$27-00-00$} & \multirow{3}{*}{$350 \mathrm{~kg}$} & \multirow{3}{*}{ 28-jul } \\
\hline & & & Field Cultivator Lt15ft & 05-dec & & & & \\
\hline & & & Roller Packer Flat Roller & 07-dec & & & & \\
\hline Barley & BARL & 25-feb & Fallplow & 23-feb & 24-feb & $27-00-00$ & $350 \mathrm{~kg}$ & 21-jul \\
\hline Maize & CORN & 01-apr & $\begin{array}{c}\text { Subsoil Chisel Plow } \\
\text { Rotary Hoe } \\
\text { Field Cultivator Lt15ft } \\
\text { Roller Packer Flat Roller }\end{array}$ & $\begin{array}{l}\text { 10-apr } \\
\text { 25-apr } \\
\text { 25-may } \\
\text { 30-may }\end{array}$ & 06-may & $08-15-15$ & $1000 \mathrm{~kg}$ & 15 -sep \\
\hline Potato & РОТА & 16-apr & $\begin{array}{l}\text { Generic Spring Plowing } \\
\text { Operation } \\
\text { Field Cultivator Lt15ft } \\
\text { Bedder disk-row } \\
\text { Beet cultivator } 8 \text { row }\end{array}$ & $\begin{array}{l}05-a p r \\
09-a p r \\
12-a p r \\
14-a p r\end{array}$ & 04-apr & 08-15-15 & $1000 \mathrm{~kg}$ & 22-aug \\
\hline Sugar beet & SGBT & 01-mar & $\begin{array}{l}\text { Generic Spring Plowing } \\
\text { Operation } \\
\text { Field Cultivator Lt15ft } \\
\text { Disk Plow Lt23ft }\end{array}$ & $\begin{array}{l}20-f e b \\
27-f e b \\
28-f e b\end{array}$ & 01-mar & $27-00-00$ & $1200 \mathrm{~kg}$ & 15-may \\
\hline Sunflower & SUNF & 25-apr & $\begin{array}{c}\text { Springtooth Harrow } \\
\text { Ge15ft }\end{array}$ & 23-mar & 22-mar & $08-15-15$ & $600 \mathrm{~kg}$ & 02-sep \\
\hline Alfalfa & ALFA & 01-oct & Fallplow & 04-oct & 02-oct & $00-20-20$ & $200 \mathrm{~kg}$ & $\begin{array}{c}\text { 05-may } \\
05 \text {-jun } \\
01 \text {-jul } \\
05 \text {-aug } \\
01 \text {-sep } \\
30 \text {-sep }\end{array}$ \\
\hline Horticulture & HORT & 03-mar & Fallplow & 02-mar & 01-mar & Elem-N & $500 \mathrm{~kg}$ & 01-aug \\
\hline Aromatic herbs & AROM & $15-f e b$ & Fallplow & 02-mar & 04-mar & Elem-N & $500 \mathrm{~kg}$ & 01-aug \\
\hline Peas & PEAS & 15-nov & Fallplow & 14-feb & 13-feb & Elem-N & $300 \mathrm{~kg}$ & 01-jul \\
\hline Canola & CANA & 06-oct & Fallplow & 16-oct & 17-oct & $08-15-15$ & $250 \mathrm{~kg}$ & 20 -jul \\
\hline Olives & OLIV & already planted & Sprgplow & 02-mar & 01-mar & Elem-N & $250 \mathrm{~kg}$ & 15-oct \\
\hline Vineyard & GRAP & already planted & Sprgplow & 15-mar & 13-apr & Elem-N & $250 \mathrm{~kg}$ & 15-aug \\
\hline
\end{tabular}

23 
24 Table B. Simulation details of SWAT model set-up and parameterization

\begin{tabular}{lc}
\hline General details & 11 \\
Simulation length [years] & 1 \\
Warm Up [years] & 1000 \\
Hydrological response Units «<HRUs >> & 121 \\
Sub-basins & Measured + TPM \\
Precipitation method & $7,850.4$ \\
Watershed area [km²] & \\
& \\
Hydrology (water balance percent) & $15 \%$ \\
Stream flow/precipitation & $74 \%$ \\
Base flow/total flow & $26 \%$ \\
Surface run-off/total flow & $9 \%$ \\
Percolation/precipitation & $0.45 \%$ \\
Deep recharge/precipitation & $80 \%$ \\
ET/precipitation & \\
& \\
Hydrological parameters (all units in mm) & \\
Average curve number & 51.57 \\
ET and transpiration & 358.1 \\
Precipitation & 447.5 \\
Surface run-off & 17.66 \\
Lateral flow & 28.81 \\
Return flow & 22.35 \\
Percolation to shallow aquifer & 39.97 \\
Recharge to deep aquifer & 2 \\
Revaporation from shallow aquifer & \\
\hline & \\
& \\
&
\end{tabular}

25

26 
27 Table C. Yearly average water associated processes to the land use. LULC: Land Use Land

28 Change, CN: Curve number, AWC: Available water content, USLE_LS: Universal soil loss

29 equation value as combined slope length factor (L) and slope steepness factor (S), IRR:

30 irrigation amount, PREC: precipitation, SURQ: Surface runoff to streams, GWQ:

31 groundwater flow and ET: evapotranspiration.

\begin{tabular}{cccccccccc}
\hline LULC & Area $\left(\mathbf{K m}^{2}\right)$ & CN & AWC (mm) & USLE_LS & IRR (mm) & PREC (mm) & SURQ (mm) & GWQ (mm) & ET (mm) \\
\hline AGRC & 39.12 & 64.07 & 328.55 & 0.34 & 0 & 391.83 & 3.22 & 8.64 & 350.19 \\
AGRL & 3.05 & 67 & 365.09 & 0.3 & 0 & 420.5 & 0.9 & 2.12 & 378.08 \\
ALFA & 0.47 & 35 & 365.09 & 0.17 & 0 & 385.62 & 0 & 0.14 & 395.64 \\
BARL & $1,783.49$ & 64.56 & 273.19 & 0.65 & 0 & 437.04 & 3.33 & 53.23 & 348.66 \\
BERM & 647.72 & 96.79 & 275.85 & 0.84 & 0 & 444.74 & 202.26 & 4.1 & 237.06 \\
FRSD & 37.28 & 45 & 251.65 & 1.43 & 0 & 476.55 & 0.03 & 49.24 & 418.51 \\
FRSE & $2,650.97$ & 35.35 & 246.29 & 1.2 & 0 & 445.12 & 0.03 & 56.77 & 368.66 \\
HAY & 11.12 & 35 & 250.98 & 1.48 & 0 & 482.67 & 0 & 62.36 & 403.6 \\
HORT & 42.57 & 67 & 258.03 & 0.21 & 1.93 & 437.86 & 1.61 & 19.87 & 398.03 \\
POTA & 5.56 & 67 & 282.08 & 0.2 & 16.63 & 408.04 & 4.15 & 14.37 & 391.14 \\
RNGE & 486.6 & 49.5 & 244.74 & 2.27 & 0 & 477.79 & 0.16 & 76.36 & 387.46 \\
SGBT & 3.57 & 67 & 328.3 & 0.21 & 6.83 & 372.37 & 2.12 & 0.58 & 365.58 \\
SUNF & 143.09 & 67.79 & 259.83 & 0.53 & 0 & 443.16 & 1.9 & 25.15 & 396.94 \\
SWRN & $1,517.10$ & 40.26 & 277.17 & 2.05 & 0 & 455.18 & 0.04 & 48.33 & 390.69 \\
WWHT & 478.17 & 63.13 & 251.91 & 0.66 & 0 & 452.89 & 2.03 & 74.57 & 344.33 \\
\hline
\end{tabular}

32

33

34 